\title{
Future accreted terranes: a compilation of island arcs, oceanic plateaus, submarine ridges, seamounts, and continental fragments
}

\author{
J. L. Tetreault ${ }^{1}$ and S. J. H. Buiter ${ }^{1,2}$ \\ ${ }^{1}$ Geodynamics Team, Geological Survey of Norway (NGU), Trondheim, Norway \\ ${ }^{2}$ Centre for Earth Evolution and Dynamics, University of Oslo, Oslo, Norway \\ Correspondence to: J. L. Tetreault (joya.tetreault@ngu.no)
}

Received: 28 May 2014 - Published in Solid Earth Discuss.: 1 July 2014

Revised: 30 October 2014 - Accepted: 4 November 2014 - Published: 4 December 2014

\begin{abstract}
Allochthonous accreted terranes are exotic geologic units that originated from anomalous crustal regions on a subducting oceanic plate and were transferred to the overriding plate by accretionary processes during subduction. The geographical regions that eventually become accreted allochthonous terranes include island arcs, oceanic plateaus, submarine ridges, seamounts, continental fragments, and microcontinents. These future allochthonous terranes (FATs) contribute to continental crustal growth, subduction dynamics, and crustal recycling in the mantle. We present a review of modern FATs and their accreted counterparts based on available geological, seismic, and gravity studies and discuss their crustal structure, geological origin, and bulk crustal density. Island arcs have an average crustal thickness of $26 \mathrm{~km}$, average bulk crustal density of $2.79 \mathrm{~g} \mathrm{~cm}^{-3}$, and three distinct crustal units overlying a crust-mantle transition zone. Oceanic plateaus and submarine ridges have an average crustal thickness of $21 \mathrm{~km}$ and average bulk crustal density of $2.84 \mathrm{~g} \mathrm{~cm}^{-3}$. Continental fragments presently on the ocean floor have an average crustal thickness of $25 \mathrm{~km}$ and bulk crustal density of $2.81 \mathrm{~g} \mathrm{~cm}^{-3}$. Accreted allochthonous terranes can be compared to these crustal compilations to better understand which units of crust are accreted or subducted. In general, most accreted terranes are thin crustal units sheared off of FATs and added onto the accretionary prism, with thicknesses on the order of hundreds of meters to a few kilometers. However, many island arcs, oceanic plateaus, and submarine ridges were sheared off in the subduction interface and underplated onto the overlying continent. Other times we find evidence of terrane-continent collision leaving behind accreted terranes $25-40 \mathrm{~km}$ thick. We posit that rheologically weak crustal layers or shear zones that were formed when the
\end{abstract}

FATs were produced can be activated as detachments during subduction, allowing parts of the FAT crust to accrete and others to subduct. In many modern FATs on the ocean floor, a sub-crustal layer of high seismic velocities, interpreted as ultramafic material, could serve as a detachment or delaminate during subduction.

\section{Introduction}

Terrane accretion is considered to be one of the main contributors to the growth of continental crust (Stern and Scholl, 2010; Clift et al., 2009b; Cawood et al., 2009). Although continental crust is lost by erosion and/or recycled into the mantle at subduction zones, crust is also added to continents at subduction zones by accretion and magmatic events. Accreted terranes can be made of tectonically added crustal units of volcanic arcs, oceanic plateaus, continental fragments, seamounts, accretionary prisms, melanges, ophiolites, and flysch. The tectonic accretion of volcanic arcs, oceanic plateaus, and seamounts to continents adds mafic juvenile crust that eventually will mature into felsic compositional continental crust by progressive magmatism and lower crustal foundering (Stern and Scholl, 2010).

The concept of accreted terranes was first born in the 1970s and has evolved greatly since (Monger et al., 1972; Irwin, 1972; Coney et al., 1980; Snoke and Barnes, 2006). Irwin (1972) was the first to introduce terranes into the geologic lexicon as "an association of geologic features, such as stratigraphic formations, intrusive rocks, mineral deposits, and tectonic history, some or all of which lend a distinguishing character to a particular tract of rocks and which 
differ from those of an adjacent terrane." It was in the sutured rock belts of different affinities (oceanic crust and island arc) in the Klamath Mountains that Irwin (1972) first coined the term after recognizing that these tectonically juxtaposed rocks must have been scraped off in a subduction zone. In following years the attributes of "suspect" or "accreted" were added to specify terranes of allochthonous affinity which were juxtaposed tectonically to autochthonous deposits on continents, such as by accretionary processes at a subduction zone (Coney, 1978; Ben-Avraham et al., 1981; Jones et al., 1982). The quest to identify and map accreted terranes led to the patchwork tapestry of terrane belts of western North America (Coney et al., 1980) and the idea that continents grew from accretionary processes at subduction zones.

In addition to identifying suspect terranes on the continents, researchers sought to map out regions of the oceanic floor that could possibly become future accreted terranes. The advancement of oceanic seismology in the 1980s led to the cataloguing of anomalous crustal regions on oceanic plates that could eventually become accreted terranes (Carlson et al., 1980; Ben-Avraham et al., 1981; Nur and BenAvraham, 1982). These anomalous crustal regions were initially called "oceanic plateaus", a term which encompassed every region of anomalously thick crust on the ocean plate. In this context, oceanic plateaus included large igneous provinces (LIPs), island arcs, hot spots, extinct mid-ocean ridges, seamounts, and submarine plateaus with continental crust (Ben-Avraham et al., 1981). Later compilations of anomalous crustal structures on the oceanic floor separated oceanic plateaus, thermal swells, and continental submarine plateaus (Schubert and Sandwell, 1989; Marks and Sandwell, 1991). Cloos (1993) designated basaltic oceanic plateaus, active spreading ridges, continental and island arc crust, continental passive margins, and seamounts as "future colliders". These compilations have focused on constraining the crustal thicknesses and volumes of oceanic plateaus, thermal swells, leaky transforms, and continental submarine plateaus (BenAvraham et al., 1981; Sandwell and MacKenzie, 1989; Schubert and Sandwell, 1989; Marks and Sandwell, 1991). In the past decade, numerous and advanced marine geophysical and geochemical studies have been undertaken to characterize the crustal composition of oceanic LIPs, submarine ridges, island arcs, continental submarine plateaus, and seamounts.

Naturally the following question was posed: can we quantify the likelihood of accretion or subduction of these crustal features? Researchers used analytical studies of the buoyancy forces of oceanic plateaus, continental fragments, and island arcs that prevented or allowed them to subduct or collide in a subduction zone (Molnar and Gray, 1979; Cloos, 1993; Moore and Wiltscko, 2004). Molnar and Gray (1979) and Moore and Wiltscko (2004) suggest the contrast between the external force of slab pull and the internal force produced by buoyant terrane crust will control the amount of terrane crust subducted or accreted. Molnar and Gray (1979) estimate that only $10 \mathrm{~km}$ of continental crust is subductable. Based on isostatic analyses of the subductability of oceanic plateaus, island arcs, and continental crust, Cloos (1993) calculated that collision would occur for oceanic plateaus with a crust $>17 \mathrm{~km}$ thick, a continental crust $>20 \mathrm{~km}$ thick, and young, hot island arcs. Seno (2008) calculated the forces in the subduction zone necessary for a crustal block of continental affinity to shear off of a subducting plate and concluded that accretion can only occur in a relatively dry (low pore pressure) subduction interface. More recently, analog and numerical geodynamic experiments have examined the subductability of oceanic LIPs, submarine ridges, island arcs, continental submarine plateaus, and microcontinents and the effects on the subduction zone dynamics after subduction (Ellis et al., 1999; van Hunen et al., 2002; Boutelier et al., 2003; Martinod et al., 2005; Espurt et al., 2008; De Franco et al., 2008; Mason et al., 2010; Afonso and Zlotnik, 2011; Tetreault and Buiter, 2012). Of course, observations of thick oceanic LIPs subducting (such as the Ontong Java and Hikurangi plateaus; Mann and Taira, 2004; Scherwath et al., 2010; Bassett et al., 2010) and the relative absence of entire island arc crusts in the geologic record (Condie and Kröner, 2013) indicate that the accretion, subduction, and collision of thick crustal regions might not always follow the analytical and geodynamic estimates. The tectonic addition of crustal material to continents at accretionary zones usually occurs by adding slivers of thrusted crustal units to the accretionary prism region (Coney et al., 1980; Snyder, 2002; Cawood et al., 2009), rather than collision and addition of the entire crustal thickness to the continent.

In the vein of earlier studies (Ben-Avraham et al., 1981; Sandwell and MacKenzie, 1989; Schubert and Sandwell, 1989; Marks and Sandwell, 1991), we catalog the regions of anomalous crust on the ocean floor and compare them to accreted terranes using new geophysical and geological studies from the last couple of decades. We group island arcs, oceanic LIPs, submarine ridges, seamounts, hot spots, submarine continental fragments, and microcontinents all as future allochthonous terranes (FATs). Although accreted terranes can also be units from accretionary prisms and melanges, these pre-accretion units are actually part of the subduction zone and are autochthonous to the convergent margin, and therefore are not covered in this study. In this paper we review the crustal compositions of modern and accreted examples of FATs and discuss the processes that lead to accretion, subduction, or collision for each of these anomalous crustal features on the ocean floor. Geophysical, geological, and geochemical studies provide us with new insight on the crustal layers and constraints on densities of FATs, and we will show in our summary that there are no significant differences between seismic velocity profiles from continental crust and mafic oceanic plateau crust. This compilation will summarize average crustal thicknesses, bulk crustal densities, and crustal structures of FATs. A better understanding of modern analogues of accreted allochthonous 
terranes will improve our understanding of the volume of crust accreted and subducted, the processes and kinematics affecting accretion and subduction, and collision. We hope therefore that this compilation will constrain future modeling studies of terrane accretion.

\section{Accretionary orogenesis processes}

Accreted terranes are typically composed of units scraped off of FATs and mixed in with other subducting sediments or crust in melange or accretionary prism formations. The FAT also undergoes severe internal deformation while accreting/subducting. We observe four types of accretion processes in the Phanerozoic geologic record: incorporation into the accretionary complex, underplating to the overriding crust (sometimes termed subcretion), obduction over the overriding plate (or flake tectonics), and collision (Fig. 1).

Incorporation of FAT crust into the accretionary prism occurs through offscraping or underplating onto the prism (Cloos and Shreve, 1988). Offscraping of FAT crust into the accretionary wedge or imbricate thrusting onto the front of the accretionary wedge (Fig. 1a) are observed often in the geologic record (Wakita and Metcalfe, 2005). In this type of accretion, the FAT crust does not subduct completely, but instead builds out the accretionary wedge seaward, as in an accretionary plate margin (Clift and Vannucchi, 2004). Landward-verging imbricate thrust faults typically shear off blocks of tens to hundreds of meters of FAT or oceanic crust (Kimura and Ludden, 1995). For example, the Oso Melange and Oso Igneous Complex in Costa Rica records the history of accreted oceanic plateaus, island arcs, and seamounts which were mixed in with accretionary prism sediments (Buchs et al., 2009).

Underplating of FAT crustal material onto the overriding plate during or after subduction, also called subcretion, is perhaps the most common type of terrane accretion. Crustal units can be offscraped and underplated onto the overriding plate by stacked thrust faults, or they can be sheared and incorporated into the subduction channel (Fig. 1b) and later exhumed as part of the melange units. Moore (1989) suggests that temperature and strain rate control whether mass transfer of material by underplating or diffusive subcretion in the subduction channel is the primary accretion method. Active underplating in a modern subduction zone is clearly observed in seismic refraction studies of the Sagami trough in Japan (Kimura et al., 2010). In the Borneo wedge, crustal units of a subducted continental fragment underplated the accretionary prism in thrust slices (Sapin et al., 2011). Thrust slices of underplated FAT crust are often interlaid with thrusted melange units, as seen in the imbricated intraoceanic arc and melange slices of the Klamath Mountains (Wright and Wyld, 1994). In addition, weak crustal layers can be activated as detachments that allow for shearing of crustal units (Zagorevski et al., 2009; Tetreault and Buiter, 2012).
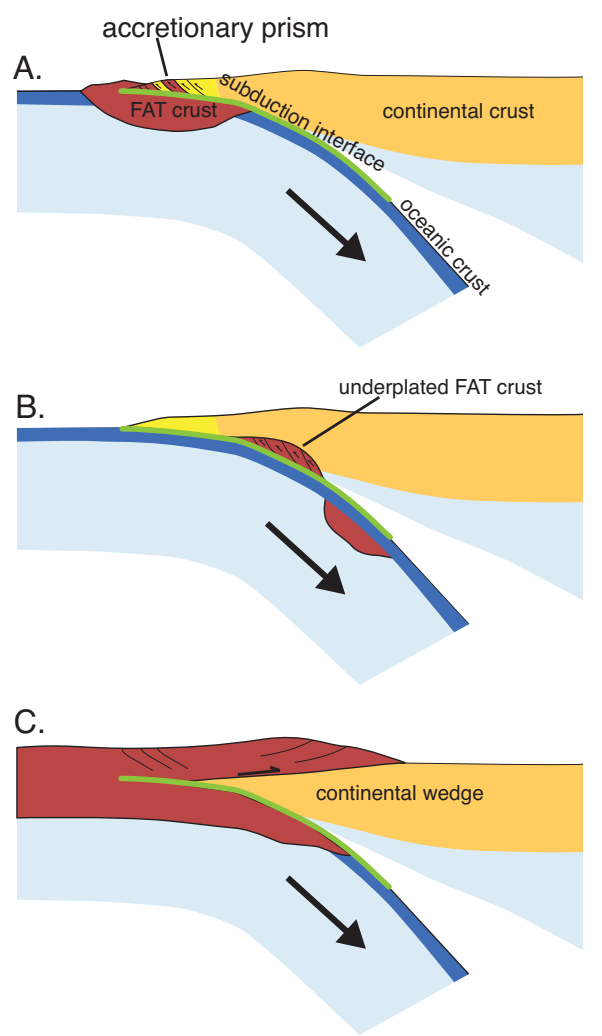

D.

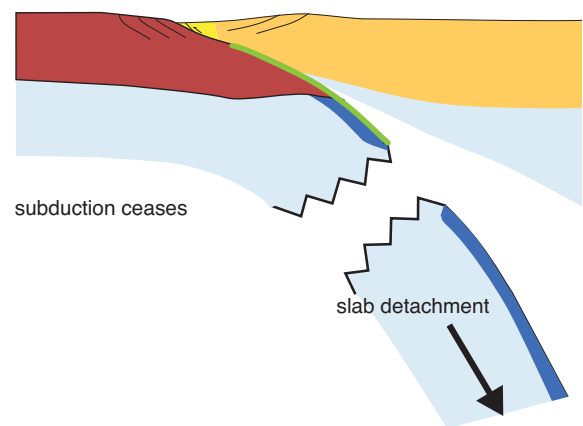

Figure 1. Cartoon schematics of FAT crust in subduction zones for four accretionary processes: (a) accretion in the accretionary prism, (b) subcretion, (c) flake tectonics, and (d) collision. In (a), sediments and crustal units from the subducting oceanic plate and FAT are scraped off and accumulated in the accretionary prism in front of the fore-arc. The majority of the FAT crust is subducted. Subcretion (b) occurs below the accretionary prism, as crustal slices of the FAT are sheared and thrust onto the overriding continent. (c) Flake tectonics is the accretionary process where FAT crust is obducted onto the overriding continent, likely over a thick, strong prism of metasedimentary rocks in the overriding plate. (d) Collision will occur for large FATs, after some of the crust has subducted and accreted. The subducting slab may eventually detach.

Flake tectonics is the process of obduction of terranes during subduction/collision on top of an overriding strong wedge (Oxburgh, 1972). Accretion of FATs via flake tectonic mechanics is most notably evident in southwestern 
Canada where the Paleozoic Quesnellia, Stikinia, and Cache Creek terranes were thrust and subsequently transported hundreds of kilometers inland over a Proterozoic metasedimentary wedge (Snyder et al., 2009; van der Velden and Cook, 2005; Cook et al., 2004). Other notable examples of accretion via flake tectonics include the Alps (Oxburgh, 1972) and the Archean greenstone belts (Hoffman and Ranalli, 1988). The paucity of flake tectonic mechanics in Phanerozoic terrane accretion is explained by the absence of a strong overriding wedge in most subduction zones (Ellis, 1988).

Intact accretion of FAT crusts by "docking" is often a collisional process (when subduction ceases) rather than an accretionary process (subduction continues after accretion) and is a method of continental growth via large volume addition of exotic crustal material (Fig. 1d). Continental fragments and composite terranes typically lead to collision. In terrane docking, it is possible to preserve the whole crustal section of terranes. Many of the larger FATs such as oceanic plateaus and continental fragments are accreted by collision. A notable example of docking of major crustal units is in Canada, where lithospheric suture zones bounding major terranes are identified with seismic refraction lines (Clowes et al., 1995). Intraoceanic island arcs are often on the overriding plate, on the receiving end of accretion processes. Arc-continent collision in this configuration allows for the overriding island arc to be added as an intact unit to the subducting continent.

An additional method of adding crustal material to continents to form suspect terranes is by back-arc basin closure and tectonic switching (Collins, 2002; Cawood and Buchan, 2007). During subduction, changing convergence velocities can lead to cycles of slab retreat and advance that can form and close a back-arc basin on the overriding plate (Collins, 2002). Triassic and Jurassic extension and formation of a back-arc basin in the North American Cordilleran was followed by basin inversion and thrusting, leading to island arc accretion through Nevada and California (Dickinson, 2006). Tectonic switching and back-arc basin closure has been used to explain the accretion of terranes in the Lachlan orogen in Australia (Collins, 2002) and the Svecofennian orogen in Sweden (Hermansson et al., 2008).

\section{Island ares}

\subsection{Island arcs: general setting}

Island arcs are volcanic island chains that form on the overriding oceanic plate at subduction zones (Fig. 2). Extinct intra-oceanic island arcs, also called remnant arcs, back arcs, or ridges, can also become accreted allochthonous terranes of island arc affinity. Continental volcanic arcs are defined as volcanic arcs built on the continental upper plate of a subduction zone and therefore excluded from this compilation. However, some oceanic island arcs are built on fragments of continental crust, most notably Japan, and can eventually be- come accreted terranes, and those special cases are included. Island arc chains are geographically curvilinear, spanning hundreds of kilometers along strike and about $100 \mathrm{~km}$ in width (Calvert, 2011). The topography of island arcs is quite striking, with the elevation rising from sea floor to sometimes a couple of kilometers above sea level over just 10 or $20 \mathrm{~km}$ distance. The locations of island arcs $(\sim 120 \mathrm{~km}$ from the trench in subduction zones; England et al., 2004) are believed to be dictated by slab dip and melting in the mantle wedge (England and Katz, 2010) and/or fluid release from the downgoing slab (Grove et al., 2009). Remnant arcs are created by either back-arc rifting of the fore-arc or abandonment due to changes in plate motion (Karig, 1972). The Izu-BoninMariana arc system is one such example: it is composed of several active island arc chains with more than one remnant back-arc produced by changing plate motions (Stern et al., 2003). Back-arc basins separate active island arcs from remnant arcs and form by extension in the upper plate due to slab rollback or mantle wedge convection (Sdrolias and Müller, 2006). Back-arc basins are composed of extended arc crust and even oceanic crust.

Island arcs are the most widely intuited contributor of continental crustal growth (Stern and Scholl, 2010), primarily because the crustal composition is believed to be most similar to the felsic continental crust. Using volume estimates from Condie and Kröner (2013), we project about $13 \%$ of post-Archean accreted terranes are oceanic island arcs and $55 \%$ are continental arcs. Cloos (1993) estimated that island arcs greater than $15 \mathrm{~km}$ in thickness are buoyant enough to collide with continental crust; however, the paucity of whole crustal sections of island arcs in the geologic record does not agree with this hypothesis (Condie and Kröner, 2013).

\subsection{Island arcs: modern examples}

There is a noticeable variation in crustal thickness and structure of modern island arcs between arc systems and even along strike within arc systems (Calvert, 2011) (Fig. 3), which can be attributed to the level of maturity in arc crustal evolution (Tatsumi et al., 2008), the amount of back arc extension (Nishizawa et al., 2007), and the magmatic production rate (Christeson et al., 2008). Mature island arc systems, such as the Izu-Bonin-Mariana system, have three crustal layers which were developed by partial melting of the initial immature basaltic arc crust (Tatsumi et al., 2008). The upper crustal layer often has a sharp velocity gradient and P-wave velocities ranging from 3 to $6 \mathrm{~km} \mathrm{~s}^{-1}$ (Fig. 3), which are interpreted to be layers of volcaniclastics, volcanic flows, and sediments. The mid-crustal layer is characterized by seismic velocities of around $6-6.5 \mathrm{~km} \mathrm{~s}^{-1}$. This low velocity layer is often interpreted to be a layer of felsic to intermediate igneous rocks in many modern oceanic island arcs (South Sandwich; Leat et al., 2003; the Izu-Bonin-Mariana system; Kodaira et al., 2007a; Takahashi et al., 2007, 2009; Tonga Arc; Crawford et al., 2003). The felsic mid-crustal unit is 
Table 1. Island arc crustal thicknesses including the crust mantle transition layer (CMTL). All thicknesses are taken from seismic interpretations except for the Tonga Arc, which was derived by gravity modeling.

\begin{tabular}{|c|c|c|}
\hline Island Arc & Thickness (km) & Reference \\
\hline Aleutian Arc & $35-37$ & Shillington et al. (2004) \\
\hline Aves Ridge & 26 & Christeson et al. (2008) \\
\hline Bonin Arc (S. Izu Active Arc) & 25 & Takahashi et al. (2009); Kodaira et al. (2007b) \\
\hline Chugoku Arc (SW. Japan) & 30 & Ito et al. (2009) \\
\hline Daito Ridge & $20-25$ & Nishizawa et al. (2005) \\
\hline N. Izu Arc & $26-32$ & Kodaira et al. (2007a) \\
\hline S. Izu Rear Arc & 18 & Takahashi et al. (2009) \\
\hline Japan (Honshu Arc) & 26 & Arai et al. (2009) \\
\hline Japan (Chikogu segment) & 30 & Ito et al. (2009) \\
\hline Kuril Arc & 33 & Nakanishi et al. (2009) \\
\hline Kyushu-Palau Ridge & 20 & Nishizawa et al. (2007) \\
\hline Lau-Colville Ridge & 15 & Karig (1970) \\
\hline Leeward Antilles Arc & 27 & Magnani et al. (2009) \\
\hline Lesser Antilles Arc & 24 & Christeson et al. (2008) \\
\hline Lesser Antilles at Montserrat & $26-34$ & Sevilla et al. (2010) \\
\hline Luzon Arc & $25-30$ & Yumul et al. (2008); Dimalanta and Yumul (2004) \\
\hline Mariana Arc & 18 & Calvert et al. (2008) \\
\hline Mariana Arc & 20 & Takahashi et al. (2007) \\
\hline W. Mariana Ridge & 17 & Takahashi et al. (2007) \\
\hline New Hebrides Arc (Vanuatu) & $27-28$ & Coudert et al. (1984); Ibrahim et al. (1980) \\
\hline Ogasawara Ridge (Bonin Ridge) & 21 & Takahashi et al. (2009) \\
\hline N. Ryukyu Arc & $23-27$ & Nakamura and Umedu (2009) \\
\hline S. Ryukyu Arc & $29-44$ & Nakamura and Umedu (2009) \\
\hline Solomon Islands & 27 & Miura et al. (2004b) \\
\hline South Sandwich Arc & 20 & Larter et al. (2003) \\
\hline Sunda Arc & 20 & Kopp et al. (2002) \\
\hline Tonga Arc & 22.2 & gravity modeling: Bryan et al. (1972) \\
\hline Average & $26 \pm 6$ & \\
\hline
\end{tabular}

produced by repetitive anatexis of the mafic lower crust (Tatsumi et al., 2008; Rioux et al., 2010). Juvenile island arcs are believed to lack this felsic middle layer, as in the cases of the Lesser Antilles and Leeward Antilles (Magnani et al., 2009; Christeson et al., 2008) and parts of the Kyushu-Palau Ridge (Nishizawa et al., 2007). The mid-crustal layer of the mature Aleutian arc, on the other hand, is inferred to be of a more mafic than intermediate composition, based on the higher seismic velocities at depths of 11-20 km (Shillington et al., 2004). The lower crustal unit of island arcs is typically characterized by seismic velocities ranging from 6.7 to $7.3 \mathrm{~km} \mathrm{~s}^{-1}$ (Fig. 3) and is interpreted to be gabbroic in composition, underlain by mafic to ultramafic cumulates. The mafic and ultramafic cumulates are sometimes classified as a separate unit from the lower crust, called the crust-mantle transition layer (CMTL) (Takahashi et al., 2007, 2009). The CMTL has typical seismic velocities around $7.0-7.6 \mathrm{~km} \mathrm{~s}^{-1}$ (Fig. 3). We include the CMTL as part of the crust because it is above the seismic Moho in modern arcs and also found above mantle rocks in the accreted Talkeetna arc in Alaska (Rioux et al., 2007; Greene et al., 2006), Kohistan arc in Pakistan (Kono et al., 2009), and Guanajuato arc in Mexico
(Lapierre et al., 1992). Seismic velocities ranging from 7.6 to $8.0 \mathrm{~km} \mathrm{~s}^{-1}$ are found below the lower crust of the Mariana arc and West Mariana rear arc in a thick layer, but the authors interpret the reflections between this layer and the lower crust as the Moho discontinuity and not the CMTL (Takahashi et al., 2007, 2008). Seismic reflections are also observed below this layer (Takahashi et al., 2007, 2008) and they are attributed to transformation of mafic materials during arc crustal generation rather than melt in the mantle (Takahashi et al., 2008; Tatsumi et al., 2008).

The average crustal thickness of island arcs (including remnant arcs), determined from the thickest regions in 26 seismic and gravity studies of island arcs, is $\sim 26 \pm 6 \mathrm{~km}$ (Table 1). Bulk crustal densities were calculated from the $\mathrm{P}$-wave velocities of 17 seismic refraction studies using the Nafe-Drake curve (Ludwig et al., 1970), the Christensen and Mooney (1995) relationships for all rocks at $10 \mathrm{~km}$ depth intervals, and the Christensen and Shaw (1970) curve based on mafic rocks from the mid-Atlantic ridge (Table 2). The densities calculated for the CMTL layer in this compilation range from 3.02 to $3.32 \mathrm{~g} \mathrm{~cm}^{-3}$ using the Christensen and Mooney (1995) relationships. These values are within the range of, if 
Table 2. Bulk crustal densities (in $\mathrm{g} \mathrm{cm}^{-3}$ ) of modern island arcs determined from seismic velocities using different seismic velocity-density relationships. Crustal densities include the density of the CMTL. Bulk densities are also reported from studies where the authors combined gravity and seismic data to determine crustal density.

\begin{tabular}{|c|c|c|c|c|}
\hline Island Arcs & $\begin{array}{l}\text { Nafe- } \\
\text { Drake }\end{array}$ & $\begin{array}{l}\text { Christensen- } \\
\text { Mooney }\end{array}$ & $\begin{array}{l}\text { Christensen- } \\
\text { Shaw }\end{array}$ & $\begin{array}{l}\text { Reported in } \\
\text { the study }\end{array}$ \\
\hline Aleutians ${ }^{1}$ & 2.70 & 2.73 & 2.73 & \\
\hline Aleutians $^{2}$ & 2.81 & 2.81 & 2.83 & \\
\hline Aleutians ${ }^{3}$ & 2.97 & 3.02 & 3.05 & \\
\hline Aves Ridge ${ }^{4}$ & 2.77 & 2.71 & 2.70 & 2.70 \\
\hline Bonin Arc (S. Izu Arc $)^{5}$ & 2.86 & 2.86 & 2.85 & \\
\hline Izu-Bonin $\mathrm{Arc}^{6}$ & 2.81 & 2.82 & 2.79 & \\
\hline S. Izu Rear Arc ${ }^{5}$ & 2.83 & 2.82 & 2.80 & \\
\hline SW. Japan ${ }^{7}$ & 2.77 & 2.80 & 2.76 & \\
\hline Kuril Arc ${ }^{8}$ & 2.65 & 2.62 & 2.51 & \\
\hline Kyushu-Palau Ridge ${ }^{9}$ & 2.83 & 2.83 & 2.84 & \\
\hline Leeward Antilles Arc ${ }^{10}$ & 2.73 & 2.71 & 2.63 & \\
\hline Lesser Antilles Arc ${ }^{4}$ & 2.76 & 2.76 & 2.70 & 2.66 \\
\hline Mariana $\operatorname{Arc}^{10}$ & 2.78 & 2.77 & 2.73 & \\
\hline W. Mariana Ridge ${ }^{11}$ & 2.65 & 2.57 & 2.46 & \\
\hline Ogasawara Ridge 5 & 2.89 & 2.91 & 2.91 & \\
\hline South Sandwich Arc ${ }^{12}$ & 2.76 & 2.73 & 2.68 & 2.89 \\
\hline Tonga Arc ${ }^{13}$ & 2.80 & 2.79 & 2.75 & \\
\hline average & $2.79 \pm 0.08$ & $2.79 \pm 0.10$ & $2.75 \pm 0.14$ & \\
\hline
\end{tabular}

References are (1) Holbrook et al. (1999), (2) Lizarralde et al. (2002),(3) Shillington et al. (2004), (4) Christeson et al. (2008), (5) Takahashi et al. (2009), (6) Kodaira et al. (2007a), (7) Ito et al. (2009), (8) Nakanishi et al. (2009), (9) Nishizawa et al. (2007), (10) Magnani et al. (2009), (11) Takahashi et al. (2007), (12) Leat et al. (2003), and (13) Crawford et al. (2003).

not slightly lower than, the densities calculated based on mineral assemblages and sub-Moho conditions ( $>0.8 \mathrm{MPa}$ and $800-1000^{\circ} \mathrm{C}$ ) for the ultramafic pyroxenites from accreted island arcs $\left(\sim 3.25-3.40 \mathrm{~g} \mathrm{~cm}^{-3}\right)$ (Jull and Kelemen, 2001; Behn and Kelemen, 2006). Three seismic refraction studies constrained their crustal structure models with gravity modeling and inferred a whole crustal density for the arcs which we compare to our calculated densities (Table 2). Coincidentally, the average island arc crustal density calculated with the Christensen and Mooney (1995) relationship is identical to the average density calculated with the Nafe-Drake curve $\left(2.79 \mathrm{~g} \mathrm{~cm}^{-3}\right)$. The average crustal densities calculated from the three relationships are lower than the bulk density of average continental crust $\left(2.83 \mathrm{~g} \mathrm{~cm}^{-3}\right.$; Christensen and Mooney, $1995)$ and the average density for oceanic crust $\left(2.86 \mathrm{~g} \mathrm{~cm}^{-3}\right.$; Carlson and Herrick, 1990).

\subsection{Island arcs: accreted examples}

Accreted island arcs are mostly identified in the geologic record as calc-alkaline volcanic units. The amount of crustal thickness that is actually accreted varies significantly throughout the geologic record. It is not common to find the entire crustal section preserved in terranes of accreted island arcs. Only a few accreted island arc terranes (i.e., Tal- keetna, Bonanza, Kohistan, Canyon Mountain, and El Paxtle arcs) contain parts of all of the original crustal layers, but these accreted layers are severely thinned. Geobarometric and geologic studies suggest original crustal thicknesses of $30-35 \mathrm{~km}$ for the Talkeetna arc (Greene et al., 2006; Hacker et al., 2008), $24 \mathrm{~km}$ for the Bonanza arc (Canil et al., 2010), $45 \mathrm{~km}$ for the Kohistan arc (Miller and Christensen, 1994), and about $30 \mathrm{~km}$ for the Canyon Mountain complex (Pearcy et al., 1990). The remaining preserved crustal thicknesses are $18 \mathrm{~km}$ thickness for the Talkeetna arc (Greene et al., 2006), $15 \mathrm{~km}$ for the Bonanza arc (Canil et al., 2010), and about $8.3 \mathrm{~km}$ for the Canyon Mountain complex (Pearcy et al., 1990). The Kohistan arc is believed to be entirely preserved in crustal thickness (Miller and Christensen, 1994; Petterson, 2010). Interestingly, the estimated original crustal thicknesses of these accreted terranes are significantly larger than the average thickness of modern island arcs, most likely because of the large uncertainty and often lack of constraints in estimating the depth of crystallization. Truncated units from all crustal layers are also found in the accreted AlisitosTeloloapan arc in Mexico (Lapierre et al., 1992) and the Alisitos Arc in Baja (Busby, 2004; Busby et al., 2006), but no estimates of original thickness have been made.

Based on the few terranes that contain units from the entire arc crust and even the upper mantle, accreted island 


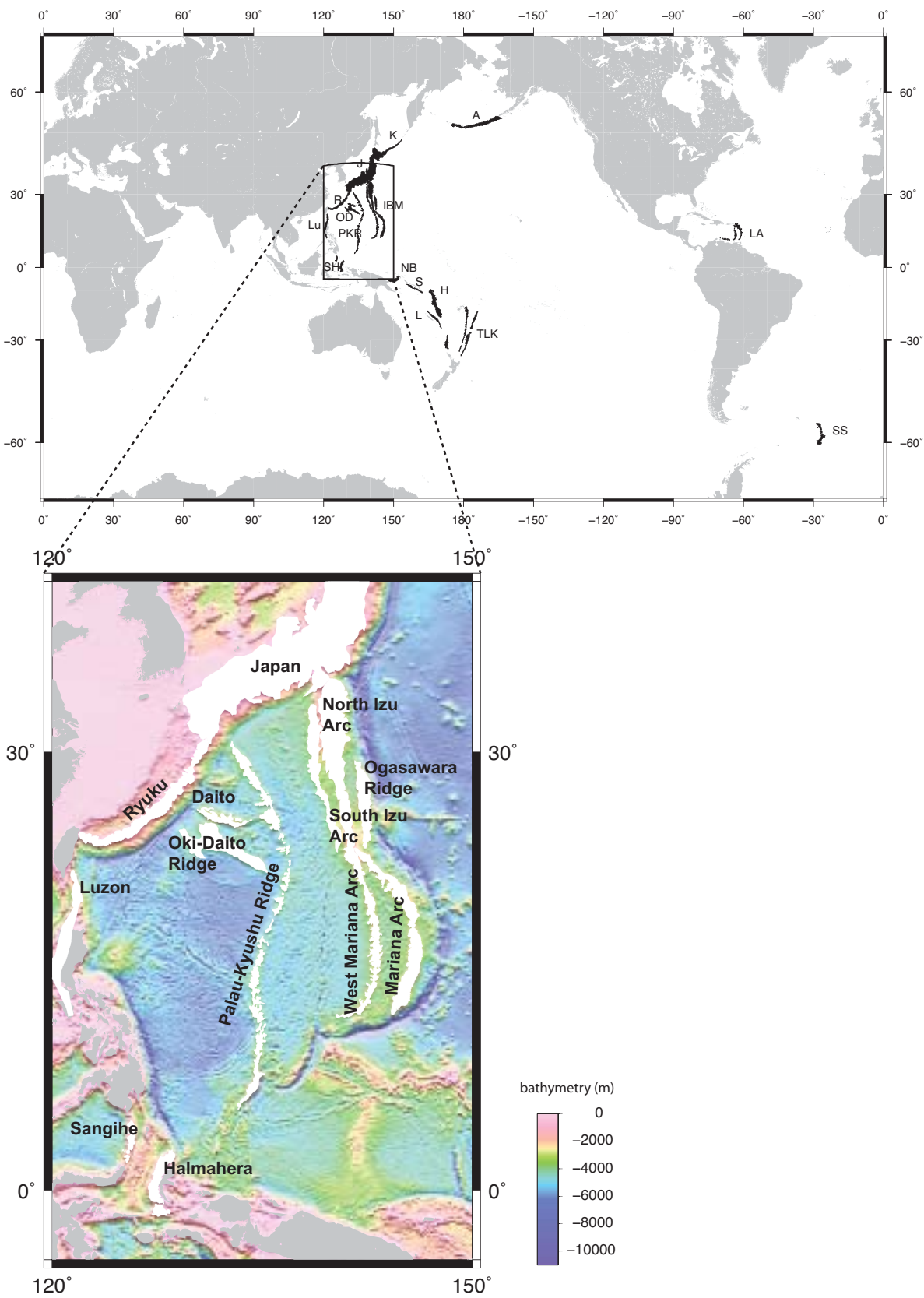

Figure 2. Global location map of island arcs (shown in black) on the present day ocean floor. Arc systems labeled on the map are: A - Aleutians, H - New Hebrides, IBM - Izu-Bonin (Ogasawara)-Mariana arc system, J - Japan Arc, K - Kuril Arc, L - Loyalty Arc, LA - Lesser and Leeward Antilles, Lu - Luzon Arc, OD - Oki-Daito system, PKR - Palau-Kyushu Ridge, NB - New Britain Arc, R Ryukyu Arc, S - Solomon Arc, SH - Sangihe-Halmahera arc system, SS - South Sandwich Arc, and TKL - Tonga-Lau-Kermadec arc system. Below is a zoom-in of the numerous oceanic island arc systems (in white) in Southeast Asia, with bathymetry from ETOPO 1 (Amante and Eakins, 2009).

arcs are composed of three crustal layers. The upper crust in accreted island arcs is mostly composed of volcaniclastics, basalt flows, tuffs, and sediments (Lapierre et al., 1992; Pearcy et al., 1990). The middle layers identified in accreted island arc suites are felsic to intermediate composition plutons such as tonalities, diorites, and trondhjemites (Fig. 3)
(Rioux et al., 2010; Greene et al., 2006). In the accreted Talkeetna arc, the middle crustal layer is composed of intermediate to felsic plutons that produce seismic velocities of $6-6.5 \mathrm{~km} \mathrm{~s}^{-1}$ (Rioux et al., 2010). The lower crust is typically mafic in composition, including garnet gabbros, layered gabbros, and pyroxene granulites (Debari and Sleep, 1991; 


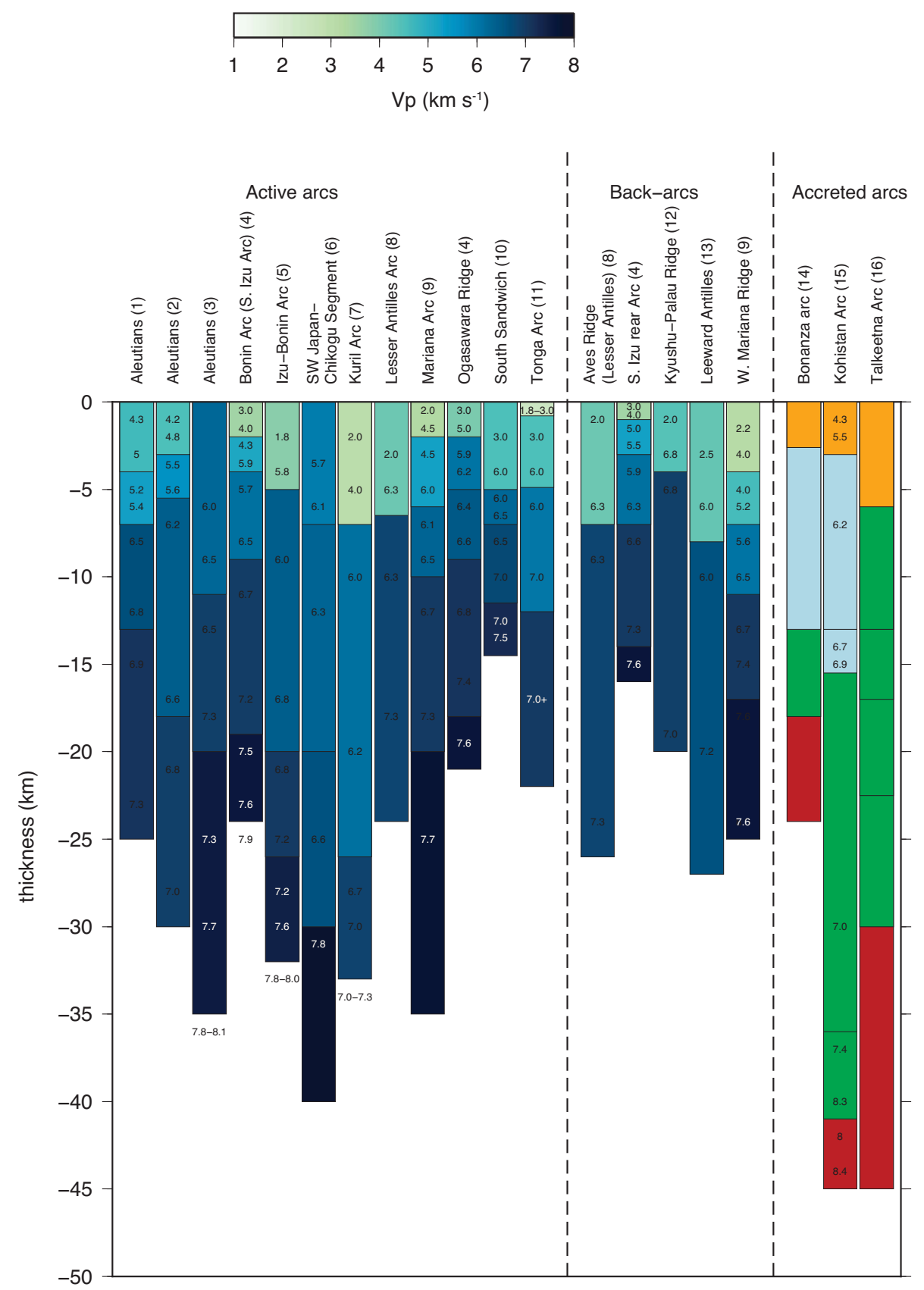

Figure 3. Seismic crustal structure of modern island arcs and calculated structure of accreted island arcs from previous studies. The thicknesses of units in the accreted arcs are calculated by geobarometric methods (Canil et al., 2010; Greene et al., 2006; Miller and Christensen, 1994) and the seismic velocities for the Kohistan units were measured in the lab (Miller and Christensen, 1994). For the accreted island arcs, orange represents upper crust, light blue represents middle crust, green is lower crust, and red represents the CMTL. References are (1) Holbrook et al. (1999), (2) Lizarralde et al. (2002), (3) Shillington et al. (2004), (4) Takahashi et al. (2009), (5) Kodaira et al. (2007a), (6) Ito et al. (2009), (7) Nakanishi et al. (2009), (8) Christeson et al. (2008), (9) Takahashi et al. (2007), (10) Leat et al. (2003), (11) Crawford et al. (2003), (12) Nishizawa et al. (2007), (13) Magnani et al. (2009), (14) Canil et al. (2010), (15) Greene et al. (2006), and (16) Miller and Christensen (1994).

Greene et al., 2006; Lapierre et al., 1992). Ultramafic cumulates such as pyroxenite gabbros and dolerites are best preserved in the accreted Kohistan arc (Kono et al., 2009; Miller and Christensen, 1994), but smaller units are also found in the El Paxtle arc in the Guerrero terrane (Lapierre et al., 1992), Talkeetna arc (Greene et al., 2006), Canyon Mountain complex (Pearcy et al., 1990), and Bonanza arc (Canil et al., 2010). Seismic velocities from the Tonsina pyroxenite 
unit of the accreted Talkeetna arc are 7.3-7.6 $\mathrm{km} \mathrm{s}^{-1}$ (Behn and Kelemen, 2006), and those from the Jijal garnet pyroxenites of the accreted Kohistan arc are 7.8-8.4 $\mathrm{km} \mathrm{s}^{-1}$ (Kono et al., 2009), correlative to the CMTL in modern island arcs.

The preserved thicknesses of crustal units of island arcs in accreted terranes varies depending on the style of accretion and collision and the subduction polarity in an arc-continent convergence zone (Draut and Clift, 2013). Because island arcs form on the overriding plate at subduction zones, wholearc accretion is most likely due to a continent entering the subduction zone on the downgoing plate before the arc is obducted or collided onto the continent. This type of tectonic accretion is currently observed at the Luzon Arc in Taiwan (Clift et al., 2009a) and in the early stages in the collision of the Banda arc with Australia (Shulgin et al., 2009). The mostly intact, accreted Kohistan arc in Pakistan is a notable example of arc-continent collision (Searle et al., 1999). But in this case the Kohistan arc is believed to have been on the subducting plate in a "backward-facing" arc-continent collision polarity (Draut and Clift, 2013). Besides arc-continent collision, island arcs collide/accrete to another FAT (such as an oceanic plateau) and create a large composite terrane that will collide, suture to continents, and preserve remnants of the island arc crust. A modern example of arc collision including a continental fragment rather than a continent is the Palawan microcontinent-Philippine arc collision (Yumul et al., 2009). Accreted examples are the Talkeetna arc in Wrangellia composite terrane in Canada (Greene et al., 2006) and the Stikine arc in Canada (English and Johnston, 2005; Johnston and Borel, 2007). Quite possibly the modern-day Ontong Java Plateau-Solomon islands in the southwest Pacific (Petterson et al., 1999) will be a future accreted composite terrane. And in the case of an island-arc-back-arc system accreting onto a continent, it is likely that the back-arc basin will be accreted along with the active and extinct island arcs. Tethyan ophiolites composed of MORBs and boninites are remnants of back-arc basin closure and obduction during arc-continent collision (Flower and Dilek, 2003).

However, in most cases only the upper $2-5 \mathrm{~km}$ of arc crust are accreted onto continents through thin-skinned thrusting and preserved. This most likely occurs when island arcs are on the subducting plate and arc material is underplated and accreted onto the overriding plate. For example, in the eastern Klamath Mountains of North America, Devonian island arc units are $2.5-3.5 \mathrm{~km}$ in thickness and include mafic pillow basalts and a felsic upper unit, indicative of upper to middle crustal layers (Dickinson, 2000). Cambrian to Ordovician island arc fragments in the Central Asia orogenic belt are bound by imbricate thrust faults (Windley et al., 2007; Wakita et al., 2013), mirroring the thrust fault-sutured arcs and back-arc basins of Southeast Asia (Pubellier and Meresse, 2013). Detachment faults produced by thinning during back-arc extension or rheologically weak crustal layers can enable accretion of island arc crustal units. Zagorevski et al. (2009) suggest that Ordovician terranes of arc and back-arc origins in the Central Newfoundland Annieopsquotch accretionary tract were accreted onto Laurentia because of low angle detachments within the arcs that were produced during back-arc extension. Also, the felsic middle crustal layer could be weakened by metasomatism from fluids released during subduction and act as a décollement layer to underplate arc crustal units onto the continent (van Staal et al., 2001).

Another possible mechanism for accretion is the delamination of the CMTL and increased buoyancy of the remaining island arc crust. The CMTL, composed of ultramafic cumulates and peridotites, is often cited as a layer that delaminates either pre- or syn-accretion (Behn and Kelemen, 2006; Garrido et al., 2007). The delamination of the ultramafic CMTL will result in a more felsic overall composition for island arcs, allowing the remaining arc crust to match better with the composition of continental crust (Takahashi et al., 2007, 2009). Densities calculated from mineral assemblages and in situ conditions from gabbronites and pyroxenites of the CMTL in accreted island arcs are 0.05$0.25 \mathrm{~g} \mathrm{~cm}^{-3}$ greater than those from mantle material for the same conditions, therefore leading to a negative buoyancy instability (Jull and Kelemen, 2001; Behn and Kelemen, 2006). Evidence for CMTL delamination is cited in trench-parallel upper mantle anisotropy observed below modern island arcs (Behn et al., 2007). Greene et al. (2006) also find that the volume of pyroxenites in the Talkeetna arc is much less than needed to produce the arc's crustal composition, and infer that this discrepancy is due to either foundering of much of the CMTL or the missing pyroxenites were not accreted. On the other hand, the Tonsina pyroxenites of the Talkeetna arc are conformably underlain by upper mantle harzburgites ( $\mathrm{Ri}$ oux et al., 2007), suggesting the unlikelihood that volumes of the pyroxenite are removed. Furthermore, the depleted rare earth element (REE) signature of the ultramafic section of the Kohistan arc indicates that it did not form from crustal fractionation but as a result of mantle and crust mixing (Garrido et al., 2007). The thickness of CMTLs cannot be clearly determined through crustal fractionation modeling, and the apparent missing thickness due to delamination may not be valid, at least for the Talkeetna arc.

\section{Oceanic plateaus, submarine ridges, and seamounts}

\subsection{Oceanic plateaus, submarine ridges, and seamounts: general setting}

Oceanic plateaus, submarine ridges, and seamounts (Figs. 4, 5) are mafic igneous regions with crust that is thicker than the surrounding oceanic crust; they are often difficult to differentiate from one another as accreted terranes (Kerr, 2003). Oceanic plateaus, submarine ridges, and seamounts all form due to excess magmatism breaching the oceanic plate. Historically, the term "oceanic plateau" has included 


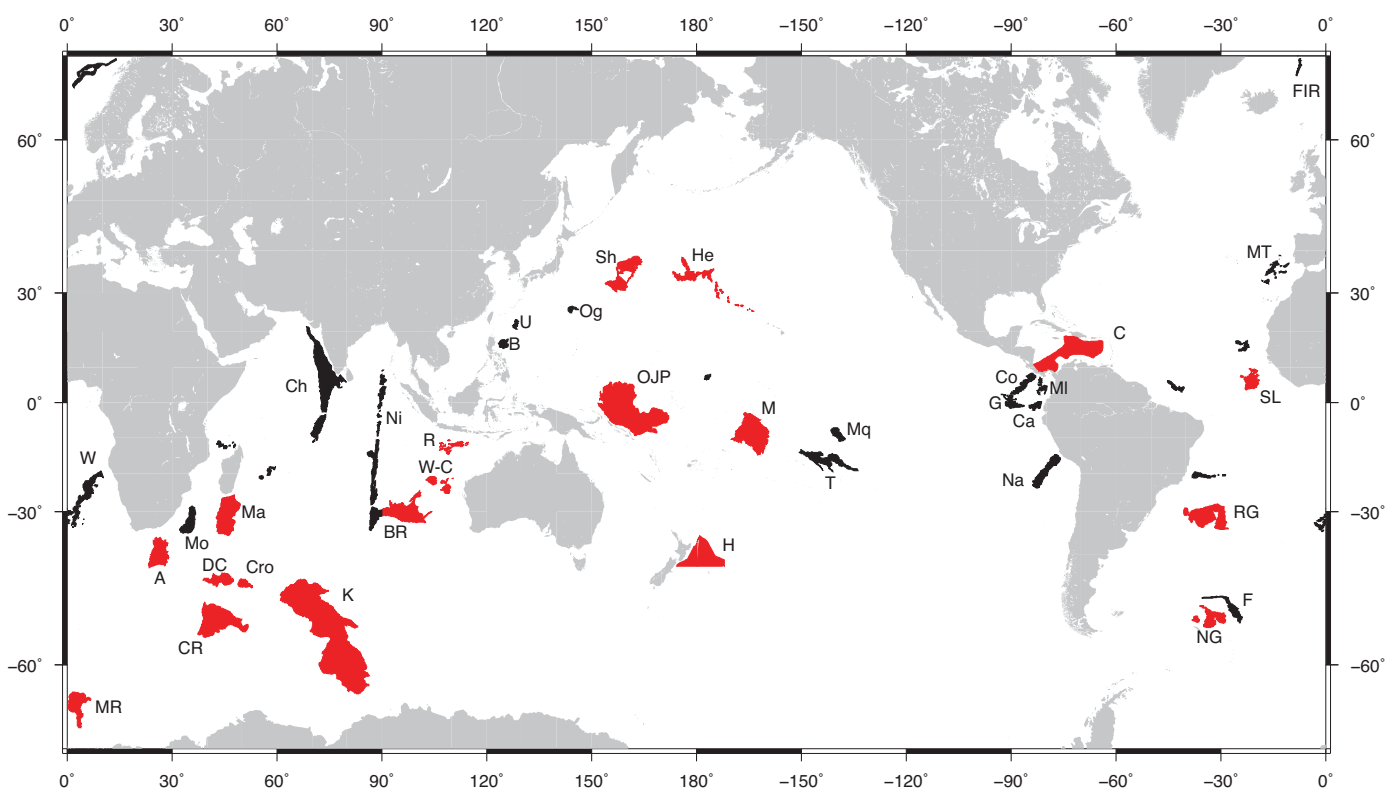

Figure 4. Location map of oceanic plateaus (shown in red) and submarine ridges (shown in black). Updated from LIP list of Coffin and Eldholm (1994) based on the definition of Bryan and Ernst (2008). Oceanic plateaus and submarine ridges labeled in the figure are: A - Agulhas Plateau, B - Benham Rise, BR - Broken Ridge, C - Caribbean Plateau, Ca - Carnegie Ridge, Ch - Chagos-Laccadive Ridge, Co - Cocos Ridge, CR - Conrad Rise, Cro - Crozet Bank, DC - Del Cano Rise, F - Falkland Ridge, FIR - Faroe-Iceland Ridge, G - Galapagos Ridge, H - Hikurangi Plateau, He - Hess Rise, K - Kerguelen Plateau, M - Manihiki Plateau, Ma - Madagascar Ridge, Ml - Malpelo Ridge, Mo Mozambique Ridge, Mq - Marquesas Ridge, MR - Maud Rise, MT - Madeira-Tore Rise, Na - Nazca Ridge, Ni - Ninetyeast Ridge, NG Northeast Georgia Rise, Og - Ogasawara Plateau, OJP - Ontong Java Plateau, R - Roo Rise, RG - Rio Grande Rise, Sh - Shatsky Rise, SL - Sierra Leone Rise, U - Urdaneta Rise, T - Tuamotu Plateau, W - Walvis Ridge, and W-C - Wallaby Plateau and Cuvier Plateau.

a large range of geographic features from extinct mid-ocean ridges, continental plateaus, remnant island arcs, oceanic flood basalts, submarine ridges, and seamount chains to hot spot tracks in the global compilations of Ben-Avraham et al. (1981), Schubert and Sandwell (1989) and Marks and Sandwell (1991). Now, oceanic plateaus are defined as a type of large igneous province (LIP) formed on oceanic crust. They are vast, wide regions of anomalously thick igneous crust and are submarine analogues to continental flood basalts (Kerr, 2003; Kerr and Mahoney, 2007). LIPS are large igneous regions on continental or oceanic crust that were rapidly emplaced (within short pulses of 1-5 Myr) over areas of more than $100000 \mathrm{~km}^{2}$ (Coffin and Eldholm, 1992, 1994; Bryan and Ernst, 2008). The origin of oceanic plateaus has been a point of vigorous discussion in the literature in terms of whether the feeder magmas originate from deep plumes or in the upper mantle based on geochemical signatures and geodynamic models (Richards et al., 1989; Foulger, 2007; Campbell and Kerr, 2007; Hastie and Kerr, 2010; Hoernle et al., 2010). Several modern oceanic plateaus were emplaced during the Cretaceous and were later rifted apart at triple junctions, such as the Kerguelen-Broken Ridge (Frey et al., 2000), Manihiki-Hikurangi-Ontong Java (Taylor, 2006; Davy et al., 2008), and Agulhas-Maud Risenortheast Georgia Rise plateaus (Parsiegla et al., 2008). The accreted Sorachi plateau is related to the Shatsky Rise oceanic plateau (Ichiyama et al., 2012) and thus could be another possible triple junction-related oceanic plateau (Sager, 2005).

Even though the seismic crustal structures of oceanic plateaus and submarine ridges appear similar, their origins are different and submarine ridges are volumetrically smaller (Bryan and Ernst, 2008). In this review, we follow the definition of oceanic plateaus as outlined by Kerr (2003), Kerr and Mahoney (2007), and Bryan and Ernst (2008) for differentiating between oceanic plateaus and submarine ridges. Some submarine ridges, such as the Nazca Ridge, Cocos Ridge, and the Tuamotu Plateau, have been previously classified as oceanic plateaus; however, based on the definition of Bryan and Ernst (2008), these mafic regions are neither voluminous enough nor formed due to rapid magmatism and therefore must be classified as submarine ridges. Submarine ridges are the result of significant magmatism produced at hot spot tracks, leaky transforms, or now-extinct mid-ocean ridges.

In addition to oceanic plateaus and submarine ridges, we include large seamounts and seamount chains in this grouping (Fig. 5). In general, seamounts are submarine volcanoes, smaller in areal extent than oceanic plateaus and submarine ridges, with geochemical signatures that suggest different sources for different seamount chains. The number of seamounts $>1.5 \mathrm{~km}$ in height currently on the ocean floor is estimated to be more than 13000 based on satellite 


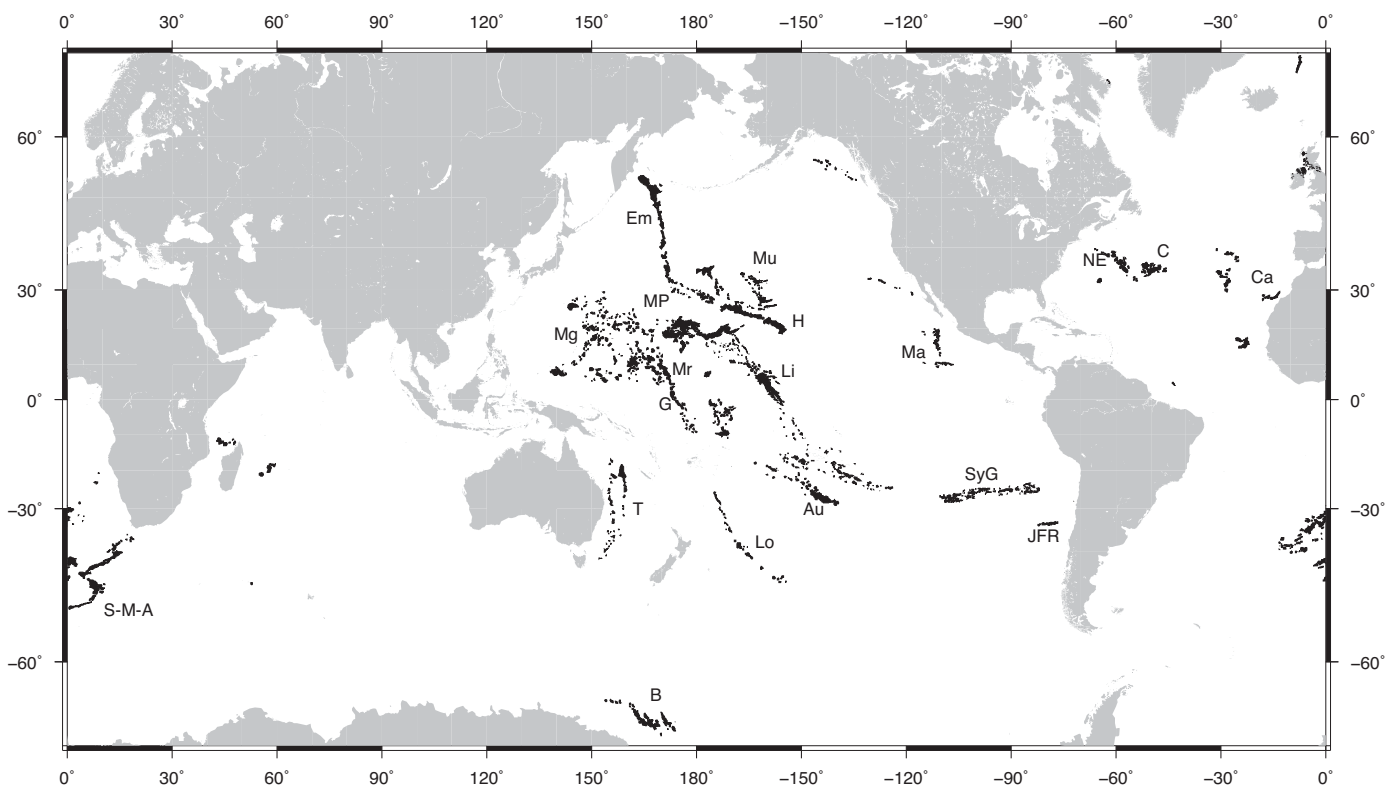

Figure 5. Location map of seamounts (shown in black). Revised from LIP list of Coffin and Eldholm (1994). Seamounts labeled are: $\mathrm{Au}$ - Austral Seamounts, B - Balleny Islands, C - Corner Seamounts, Ca - Canary Islands, Em - Emperor Seamounts, G - Gilbert Seamounts, H - Hawaii, JFR - Juan Fernandez Ridge, Li - Line Islands, Lo - Louisville Ridge, Ma - Mathematician Seamounts, Mg Magellan Seamounts, Mr - Marshall Seamounts, Mu - Musician Seamounts, MP - mid-Pacific Mountains, NE - New England Seamounts, SyG - Sala y Gomez chain, S-M-A - Shona-Meteor Rise-Agulhas Ridges, T - Tasmantid Seamounts.

altimetry (Wessel et al., 2010), and these numerous features often alter subduction zone by blocking the subducting interface or causing uplift in the accretionary prism (Watts et al., 2010). Seamounts can be formed by various processes: they can be the result of upper mantle mini-convection cells under mid-ocean ridges or transforms (Buck and Parmentier, 1986), deep mantle upwellings, short-lived hotspot volcanism, upper asthenospheric upwelling, and lithospheric cracking (Forsyth et al., 2006; Briais et al., 2009; Sandwell and Fialko, 2004). The geochemical signature of mafic accreted terranes is important in helping to determine if the accreted terrane was originally a plume-derived oceanic plateau, hot spot track submarine ridge, or the product of excess upper mantle magmatism.

\subsection{Oceanic plateaus, submarine ridges, and seamounts: modern examples}

Oceanic plateau and submarine ridge bathymetry is generally $2-3 \mathrm{~km}$ above the surrounding ocean crust. Oceanic plateaus and submarine ridges have similar crustal thicknesses, and, from 32 seismic and geophysical studies, their combined average crustal thickness is approximately $21 \pm 4 \mathrm{~km}$ (Table 3 ). Even though the $33 \mathrm{~km}$-thick Ontong Java Plateau is commonly used to exemplify the typical crustal thickness of an oceanic plateau, it is anomalously thick for oceanic plateaus (Fig. 6). Oceanic plateaus and submarine ridges typically have a sedimentary layer, upper crust, lower crust, and mafic underplating identified in seismic interpretations, although several oceanic plateaus and submarine ridges have an additional middle crustal layer (Fig. 6). Seismic refraction studies indicate an upper layer of $1-4 \mathrm{~km}$ thickness of low seismic velocities, correlated to limestones, pelagic sediments, and volcaniclastic sediments. Underlying that is the upper crust with P-wave velocities of $4.5-6.0 \mathrm{~km} \mathrm{~s}^{-1}$, commonly interpreted as mixed basaltic flows and pelagic material, altered basalts, and other submarine flows. The upper crust is sometimes correlated to oceanic layer 2 because of the similar seismic velocities. In oceanic plateaus and submarine ridges where three crustal layers are identified, the upper crust has very low seismic velocities $\left(3.5-4.5 \mathrm{~km} \mathrm{~s}^{-1}\right)$ and the middle crust has velocities typical of basalts $\left(5.0-6.0 \mathrm{~km} \mathrm{~s}^{-1}\right)$. The lower crust typically has seismic velocities of $6.5-7.0 \mathrm{~km} \mathrm{~s}^{-1}$ in all oceanic plateaus and submarine ridges. Over-thickened lower crusts are common in this group of FATs, especially in submarine ridges. The lower crust is often interpreted to be gabbroic or correlative to oceanic crust layer 3 . We caution against relating crustal units of this FAT to oceanic crust because oceanic plateaus and submarine ridges are formed differently from typical oceanic crust. Many oceanic plateaus and submarine ridges have a basal unit of high seismic velocities $\left(7.0-7.9 \mathrm{~km} \mathrm{~s}^{-1}\right)$, which is highlighted in a compilation by Ridley and Richards (2010). Grevemeyer and Flueh (2000) and Gupta et al. (2010) suggest that this mafic basal unit is underplated material due to plume magmatism. Early studies have suggested that the high seismic velocity lower crustal layer was representative of a ductile layer that occurs 
Table 3. Crustal thicknesses of oceanic plateaus and submarine ridges. Thicknesses are derived from seismic studies unless otherwise noted. ${ }^{1}$ The crustal thickness was extrapolated in the original study because the Moho was not imaged.

\begin{tabular}{|c|c|c|}
\hline $\begin{array}{l}\text { Oceanic plateaus } \\
\text { and submarine ridges }\end{array}$ & Thickness $(\mathrm{km})$ & Reference \\
\hline Agulhas Plateau & 20 & Parsiegla et al. (2008) \\
\hline S. Agulhas Plateau & 25 & Gohl and Uenzelmann-Neben (2001) \\
\hline Alpha Ridge & 38 & Dove et al. (2010) \\
\hline Broken Ridge & 20.5 & Francis and Raitt (1967) \\
\hline Caribbean Plateau & $10-20$ & Mann and Taira (2004); White et al. (1998); Mauffret and Leroy (1997) \\
\hline Carnegie Ridge & $13-19$ & Sallares et al. $(2005,2003)$ \\
\hline Cocos Ridge & 21 & Walther (2003) \\
\hline Crozet Plateau & 17 & Recq et al. (1998) \\
\hline Del Cano Rise & 17.5 & Goslin et al. (1981) \\
\hline Eauripik Ridge & $16^{1}$ & Den et al. (1971) \\
\hline Faroe-Iceland Ridge & 23 & Bohnhoff and Makris (2004) \\
\hline Hikurangi Plateau & $16-23$ & gravity modeling: Davy et al. (2008) \\
\hline N. Kerguelen Plateau & 17 & Charvis et al. (1995) \\
\hline S. Kerguelen Plateau & $21-25$ & Operto and Charvis (1995) \\
\hline Laccadive Ridge & 24 & Gupta et al. (2010) \\
\hline Madagascar Ridge & 25 & Sinha et al. (1981) \\
\hline Madeira-Tore Rise & $17-18$ & Peirce and Barton (1991) \\
\hline Maldive Ridge (Chagos Laccadive) & 15 & Francis and George G. Shor (1966) \\
\hline Malpelo Ridge & 21 & Marcaillou et al. (2006) \\
\hline Manihiki Plateau & $21.4^{1}, 25$ & Hussong et al. (1979); gravity modeling: Viso et al. (2005) \\
\hline Marquesas Island & $15-17$ & Caress et al. (1995) \\
\hline Maud Rise & $11-14$ & Ørsted Satellite data: Kim et al. (2005) \\
\hline Mozambique Ridge & $22-24$ & Konig and Jokat (2010); Hales and Nation (1973) \\
\hline Nazca Ridge & $18-21$ & Hagen and Moberly (1994); Woods and Okal (1994); Hampel et al. (2004) \\
\hline Ninetyeast Ridge & 24 & Grevemeyer et al. (2000) \\
\hline Ogasawara Plateau & $>20$ & Kaneda et al. (2005) \\
\hline Ontong Java Plateau & 33 & Miura et al. (2004b) \\
\hline Rio Grande Rise & $11-12$ & gravity modeling: Mohriak et al. (2010) \\
\hline Roo Rise & $12-18$ & Shulgin et al. (2011) \\
\hline Shatsky Rise & 26 & Gettrust et al. (1980) \\
\hline Tuamotu Plateau & 21 & Patriat et al. (2002) \\
\hline Wallaby Plateau & 18 & Mihut and Muller (1998) \\
\hline Walvis Ridge & 12.5 & Chave (1979) \\
\hline Zenith Plateau & 18 & Mihut and Muller (1998) \\
\hline Average & $21 \pm 4$ & \\
\hline
\end{tabular}

in crust greater than $15 \mathrm{~km}$ thick (Schubert and Sandwell, 1989). However, the theory that all large oceanic igneous provinces will have a ultramafic layer was debunked by the compilation of Ridley and Richards (2010).

We calculated an average crustal density from the Pwave velocities from 23 seismic refraction studies of oceanic plateaus and submarine ridges (Table 4). The average crustal density is estimated to be $2.84 \mathrm{~g} \mathrm{~cm}^{-3}$ from the Christensen and Mooney (1995) depth-dependent relationship, $2.84 \mathrm{~g} \mathrm{~cm}^{-3}$ using the Nafe-Drake curve (Ludwig et al., 1970), and $2.82 \mathrm{~g} \mathrm{~cm}^{-3}$ with the Christensen and Shaw (1970) depth-dependent relationship (Table 4). Interestingly, these values are close to the densities of average continental crust (2.83 $\mathrm{g} \mathrm{cm}^{-3}$; Christensen and Mooney, 1995) and average oceanic crust $\left(2.86 \mathrm{~g} \mathrm{~cm}^{-3}\right.$; Carlson and Herrick, 1990). Generally, the densities of oceanic plateaus and submarine plateaus calculated from the Nafe-Drake and Christensen-Mooney relationships are similar to the densities determined in combined seismic-gravity studies (Table 4).

For our review on crustal structure we focus only on large submarine volcanoes $(>3 \mathrm{~km}$ high) which are included in the list of LIPs by Coffin and Eldholm (1994). Many of these large seamounts have heights of $3-5 \mathrm{~km}$ above the surrounding ocean floor. The seismic crustal structure of seamounts consists of one or two layers and may contain a thick intrusive volcanic core. Seamounts are volcanoes build up on top of oceanic crust (Koppers and Watts, 2010). The 
Table 4. Bulk crustal densities of oceanic plateaus and submarine ridges. Bulk crustal densities (in $\mathrm{g} \mathrm{cm}^{-3}$ ) are determined from seismic velocities using different seismic velocity-density relationships. Bulk densities are also reported from studies where the authors combined gravity and seismic data to determine crustal density. References are (1) Parsiegla et al. (2008), (2) Gohl and Uenzelmann-Neben (2001), (3) Francis and Raitt (1967), (4) Sallares et al. (2003), (5) Recq et al. (1998), (6) Walther (2003), (7) Bohnhoff and Makris (2004), (8) Charvis and Operto (1999), (9) Operto and Charvis (1995), (10) Gupta et al. (2010), (11) Sinha et al. (1981), (12) Peirce and Barton (1991), (13) Hussong et al. (1979), (14) Caress et al. (1995), (15) Hales and Nation (1973), (16) Hampel et al. (2004), (17) Grevemeyer et al. (2000), (18) Miura et al. (2004b), (19) Shulgin et al. (2011), (20) Den et al. (1969), and (21) Patriat et al. (2002).

\begin{tabular}{|c|c|c|c|c|}
\hline $\begin{array}{l}\text { Oceanic plateaus } \\
\text { and submarine ridges }\end{array}$ & $\begin{array}{l}\text { Nafe- } \\
\text { Drake }\end{array}$ & $\begin{array}{l}\text { Christensen- } \\
\text { Mooney }\end{array}$ & $\begin{array}{l}\text { Christensen- } \\
\text { Shaw }\end{array}$ & $\begin{array}{l}\text { Reported in } \\
\text { the study }\end{array}$ \\
\hline Agulhas Plateau ${ }^{1}$ & 2.85 & 2.85 & 2.84 & \\
\hline S. Agulhas Plateau ${ }^{2}$ & 2.82 & 2.80 & 2.75 & 3.03 \\
\hline Broken Ridge $^{3}$ & 2.82 & 2.82 & 2.80 & \\
\hline Carnegie Ridge ${ }^{4}$ & 2.85 & 2.85 & 2.83 & 2.89 \\
\hline Cocos Ridge ${ }^{5}$ & 2.91 & 2.93 & 2.94 & 2.93 \\
\hline Crozet Plateau $^{6}$ & 2.70 & 2.63 & 2.53 & 2.62 \\
\hline Faroe-Iceland Ridge ${ }^{7}$ & 2.82 & 2.83 & 2.80 & \\
\hline N. Kerguelen ${ }^{8}$ & 2.90 & 2.92 & 2.92 & \\
\hline S. Kerguelen Plateau 9 & 2.76 & 2.76 & 2.71 & \\
\hline Laccadive Island $^{10}$ & 2.87 & 2.89 & 2.88 & \\
\hline Madagascar Ridge ${ }^{11}$ & 2.89 & 2.89 & 2.89 & 2.89 \\
\hline Madeira-Tore Rise ${ }^{12}$ & 2.77 & 2.74 & 2.68 & 2.90 \\
\hline Malpelo Ridge ${ }^{4}$ & 2.91 & 2.90 & 2.91 & 2.86 \\
\hline Manihiki Plateau $^{13}$ & 2.79 & 2.80 & 2.77 & \\
\hline Marquesas Island ${ }^{14}$ & 2.91 & 2.87 & 2.87 & \\
\hline Mozambique Ridge ${ }^{15}$ & 2.70 & 2.70 & 2.62 & \\
\hline Nazca Ridge $^{16}$ & 2.88 & 2.89 & 2.89 & 2.88 \\
\hline Ninetyeast Ridge $^{17}$ & 3.01 & 3.04 & 3.08 & \\
\hline Ontong Java Plateau ${ }^{13}$ & 2.85 & 2.87 & 2.85 & \\
\hline Ontong Java Plateau ${ }^{18}$ & 2.88 & 2.91 & 2.90 & \\
\hline Roo Rise ${ }^{19}$ & 2.75 & 2.74 & 2.68 & 2.75 \\
\hline Shatsky Rise ${ }^{20}$ & 2.96 & 2.97 & 3.00 & \\
\hline Tuamotu Plateau ${ }^{21}$ & 2.80 & 2.79 & 2.74 & 2.74 \\
\hline Average & $2.84 \pm 0.08$ & $2.84 \pm 0.09$ & $2.82 \pm 0.13$ & $2.85 \pm 0.12$ \\
\hline
\end{tabular}

uppercrustal layers of seamounts and oceanic crust correlate with the seismic velocities of basalts. The lower crustal units are interpreted to be gabbros and sheeted dikes. Many seamounts, such as the those in the O'Higgins and $\mathrm{Mu}$ sician seamount chains, have two crustal layers similar to oceanic crust and no seismically discernable intrusive core (Kopp et al., 2003, 2004). Other submarine volcanics, such as Great Meteor seamount and Marcus-Wake seamount chain, have a thick layer that is seismically different from the surrounding oceanic crust and is interpreted as the volcanic core (Weigel and Grevemeyer, 1999; Kaneda et al., 2010). In some seamounts, such as the Hawaiian chain (Leahy et al., 2010) and La Reunion (Charvis et al., 1999), the oceanic crust is underplated by a seismically fast layer. Yet other submarine volcanics, including the Louisville hot spot track (Contreras-Reyes et al., 2010), Musician seamounts (Kopp et al., 2003), O’Higgins Seamount (Kopp et al., 2004), and Marcus-Wake seamount chain (Kaneda et al., 2010), do not have any seismic high-velocity layer below the crust. The high seismic velocities found in the Louisville and MarcusWake seamount chains are attributed to mafic intrusions in the lower crust (Contreras-Reyes et al., 2010; Kaneda et al., 2010). The subcrustal high-velocity layer in other seamounts is theorized to be from mafic dikes formed as a lithostatic response to loading (Hawaii: Leahy et al., 2010), hot spot material (La Reunion: Charvis et al., 1999), or hydrated lithosphere (O’Higgins seamount: Kopp et al., 2004).

\subsection{Oceanic plateaus, submarine ridges, and seamounts: accreted examples}

Accreted oceanic plateaus and submarine ridges are typically identified in the geologic record as mafic to ultramafic basalts unit in accreted terranes. Kerr (2003) presents a diagnostic criteria for identifying ancient oceanic plateaus in the geological record based on geology, petrology, and geochemistry. Oceanic plateaus are composed mainly of 


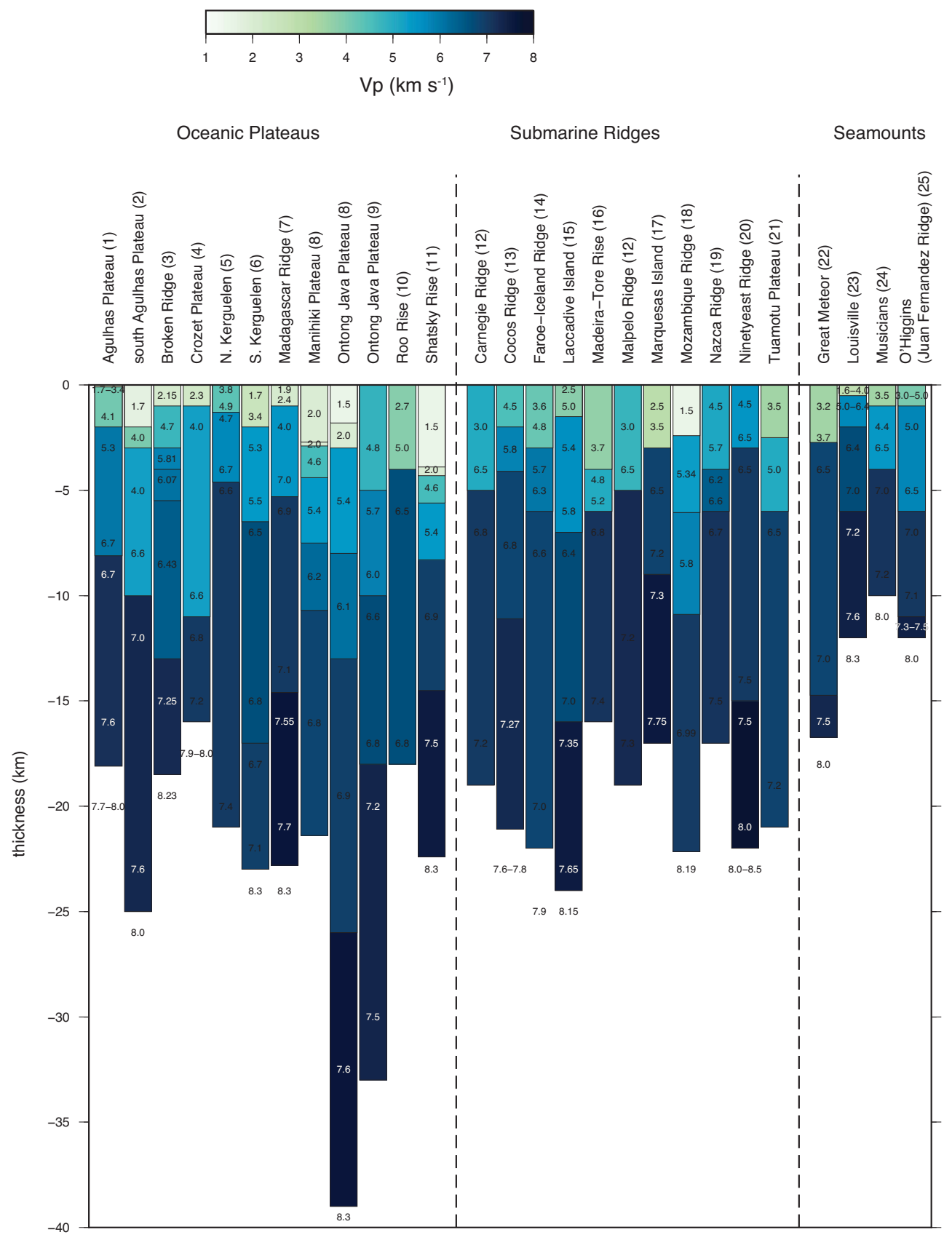

Figure 6. Crustal structures of modern oceanic plateaus and submarine ridges from seismic imaging studies. References are (1) Parsiegla et al. (2008), (2) Gohl and Uenzelmann-Neben (2001), (3) Francis and Raitt (1967), (4) Recq et al. (1998), (5) Charvis and Operto (1999), (6) Operto and Charvis (1995), (7) Sinha et al. (1981), (8) Hussong et al. (1979), (9) Miura et al. (2004b), (10) Shulgin et al. (2011), (11) Den et al. (1969), (12) Sallares et al. (2003), (13) Walther (2003), (14) Bohnhoff and Makris (2004), (15) Gupta et al. (2010), (16) Peirce and Barton (1991), (17) Caress et al. (1995), (18) Hales and Nation (1973), (19) Hampel et al. (2004), (20) Grevemeyer et al. (2000), (21) Patriat et al. (2002), (22) Weigel and Grevemeyer (1999), (23) Contreras-Reyes et al. (2010), (24) Kopp et al. (2003), and (25) Kopp et al. (2004).

tholeiiticbasalts with minor amounts of picrites and komatiites and are geochemically distinct from mid-ocean ridge basalt (MORB)-type and ocean-island basalt (OIB)-type mantle sources (Kerr, 2003; Hastie and Kerr, 2010). Depending on their origin, submarine ridge basalts can also have
MORB or ocean-island basalt OIB signatures. It is quite likely that many greenstones and mafic accreted units, identified as accreted ophiolites or oceanic crust, may actually be oceanic plateaus (see Table 4 in Kerr et al., 2000). For example, the hotspot-related greenstones of the Chugoku 
and Chichibu belts in Japan were reinterpreted as accreted oceanic plateau/submarine ridges rather than the earlier inference of mid-ocean ridge basalts, based on high $\mathrm{Zr} / \mathrm{Y}$ ratios that are more similar to OIB geochemical signatures (Tatsumi et al., 2000).

The total amount of preserved crustal structure and thickness of oceanic plateaus varies in the observed geological record of accreted terranes. Sometimes the entire crustal thickness is preserved in accreted terranes, as in the Triassic Wrangellia terrane of North America, or only truncated units from all crustal layers are found, as in the accreted Gorgona and Columbia oceanic plateaus of South America. Seismic refraction studies indicate that the total thickness of the Wrangellia composite terrane crust is about $25^{+} \mathrm{km}$ in Vancouver (Ramachandran et al., 2006; Clowes et al., 1995) and $30 \mathrm{~km}$ in Alaska (Brennan et al., 2011). Approximately $6 \mathrm{~km}$ of exposed stratigraphic thickness, correlated to the sedimentary and upper crustal layers of the Wrangellia oceanic plateau, is found in Vancouver Island (Greene et al., 2010). Wrangellia's exposed units are composed of limestone and pelagic sediments, pillow lavas, massive flood basalts, subaerial and submarine flows, and olivine-rich basalts (Greene et al., 2009, 2010). In other accreted oceanic plateaus, the preserved crustal thicknesses can be as low as $2-7 \mathrm{~km}$ thick. The total reconstructed thickness of the accreted Columbia oceanic plateau is only $8-15 \mathrm{~km}$, but units from all of the original crustal layers are found (Kerr et al., 1998). The accreted Colombian oceanic plateau also has preserved units of the ultramafic layer below the lower crust, which include olivine gabbronorites and pyroxenites (Kerr et al., 1998). In Ecuador, fragments of the Gorgona oceanic plateau include pillow basalts, dolerite sheets, and gabbros of the upper and mid crust, overlying the plume-derived magmas of the lower crust in thin-skinned thrust sheets (Kerr and Tarney, 2005; Kerr et al., 1998).

Accreted submarine ridges and seamounts are typically only truncated units of crustal layers. In Central America, various "ophiolitic" units are found with OIB geochemical signatures, which are interpreted as hotspot-related seamounts or submarine ridges (Hoernle et al., 2002; Geldmacher et al., 2008; Buchs et al., 2009). The enigmatic Siletz terrane of northern California and Oregon is composed of volcanics with OIB signatures that have been variously interpreted as a hot spot track, slab window, and mid-ocean ridge (Schmandt and Humphreys, 2011; McCrory and Wilson, 2013). Examples of accreted seamounts, identified primarily by their OIB signature, are the alkali basaltic units found in Japan (Isozaki et al., 1990). Typical seamountderived terranes include thin-skinned units of radiolarian cherts, limestones, serpentinized peridotites, layered gabbros, and alkali basalts that are on the order of hundreds of meters thick (Geldmacher et al., 2008; Buchs et al., 2009). Accreted ocean-island basalts, interpreted to be remnants of seamounts, are often found within accretionary complexes (e.g., Cache Creek terrane: Johnston and Borel, 2007). Ac- creted seamounts are often "decapitated" in the accretionary prism instead of underplated to the overriding plate. The seamount terranes of the Oso Igneous Complex in Costa Rica are within an accretionary prism complex, suggesting that the seamounts were decapitated within the prism and subsequently accreted to the Central American active margin (Buchs et al., 2009). Watts et al. (2010) suggest that even small seamounts can be accreted if the subduction channel is narrow, highly coupled, or if the seamount is regionally compensated by a thick, strong lithosphere.

Accretion of oceanic plateaus and large submarine ridges can occur as collision and whole crustal addition to a continent, or by underplating and accretion of sheared crustal units. Kerr et al. (2000) suggest that after mafic oceanic plateaus are accreted or collided, causing the subduction zone to jump, silicic magmas intrude and "mature" the accreted plateau lithology towards a more continental crust lithology. The basal cumulate layer may be a ductile layer that serves as a detachment to allow for underplating, an idea originally speculated by Schubert and Sandwell (1989) to develop in plateaus that exceed $15 \mathrm{~km}$ in thickness based on the rheological relationship of strength with depth. Even though this layer is not found in all LIPs and seamounts of great thicknesses (Ridley and Richards, 2010) (Fig. 6), the cumulate or underplated magma layer could definitely serve as a ductile layer to initiate detachment within the subduction zone. The Colombian (Gorgona) oceanic plateau is the only documented accreted plateau that has accreted units of the basal ultramafic cumulate layer, most likely due to the onset of collision early after plateau formation (Kerr et al., 1998), leading us to hypothesize that this ultramafic basal layer commonly serves as a detachment layer; therefore it is not observed in other accreted oceanic plateaus. More commonly, detachments at shallower depths will allow for obduction and imbrication of the upper units, as observed in the upper basaltic units of the Caribbean oceanic plateau that were obducted in the Caribbean islands and Ecuador (Kerr et al., 1997; White et al., 1998) and in the basaltic units of the Ontong Java Plateau onto Malaita island (Petterson et al., 1997). In the case of the active oceanic plateaucontinent collision of the Hikurangi Plateau with the North Island of New Zealand, obduction of upper volcanics, limestones, and basalt units are observed in the accretionary prism (Davy et al., 2008), while the majority of the plateau crust is subducting and underplating New Zealand (Scherwath et al., 2010). Modern tectonic accretion of submarine ridges with continental fragments is observed in the accretionary system of Southeast Asia, where future collision of the Benham plateau with the Philippine arc is predicted (Yumul et al., 2009) or has already initiated in the thrust faults of the East Luzon Trough (Queaño et al., 2009). Similarly, the Roo Rise and Ogasawara Plateau are converging on the Sunda continental arc and Izu-Bonin oceanic arc, respectively. Much like the subduction of the Hikurangi Plateau under New Zealand (Scherwath et al., 2010), the Roo Rise and 

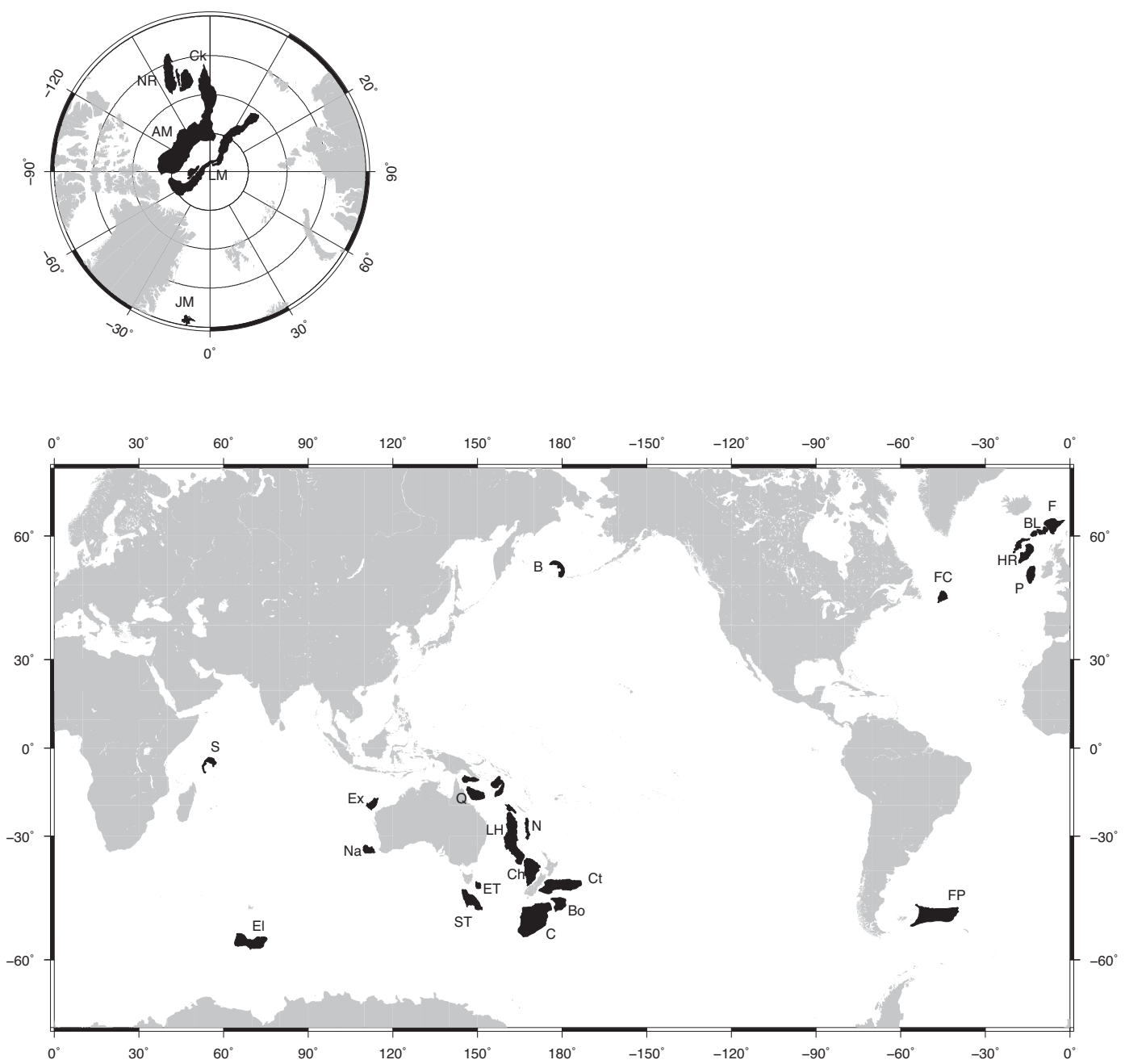

Figure 7. Location map of continental fragments (shown in black) compiled for this study. Continental fragments labeled are: AM - Alpha Mendelev Ridge, B - Bower's Ridge, Bo - Bounty Plateau, BL - Bill Bailey and Lousy banks, C - Campbell Plateau, Ch - Challenger Plateau, Ck - Chukchi Plateau, Ct - Chatham Rise, El - Elan Bank, Ex - Exmouth Plateau, ET - East Tasman Plateau, F - Faroe Bank, FC - Flemish Cap, FP - Falkland Plateau, HR - Hatton and Rockall Banks, JM - Jan Mayen, LH - Lord Howe Rise, LM - Lomonosov Ridge, Na - Naturaliste Plateau, N - Norfolk and Fairway Ridges, NR - Northwind Ridge, P - Porcupine Bank, Q - Queensland Plateau, $\mathrm{S}$ - Seychelles, and ST - South Tasman Plateau.

Ogasawara Plateau are initially subducting and underplating their respective fore-arc regions (Shulgin et al., 2011; Miura et al., 2004a).

\section{Continental fragments and microcontinents}

\subsection{Continental fragments and microcontinents: general setting}

Continental fragments, microcontinents, and continental ribbons are submarine regions of continental crust on the oceanic plate (Fig. 7) that are the result of rifting events on passive margins and retreating active margins. Continental fragments are bound by oceanic crust on one side and thick sedimentary basins overlying extremely thinned continental crust on the other. In some cases, extension proceeded far enough in the failed rifts separating continental fragments from the interior that exhumed and serpentinized mantle directly underlies the basin sediments. Exhumed mantle is inferred from seismic and potential field studies for the Porcupine Basin (Kimbell et al., 2010), Phu Khanh Basin (Savva et al., 2013), and the Santos Basin (Zalán et al., 2011). Microcontinents, such as Jan Mayen and the Seychelles, are surrounded by oceanic crust. Modern continental fragments on the ocean floor include the Rockall Bank, Hatton Bank, Campbell Plateau, Lord Howe Rise, and the Norfolk Rise (Fig. 7). Continental fragments and microcontinents are theorized to form as a result of plume interaction with passive margins (Müller et al., 2001; Gaina et al., 2003), localized 
thinning on the basins surrounding continental fragments (Peron-Pinvidic and Manatschal, 2010), differential thinning due to inherited structural grains from ancient sutures zones (Hitchen, 2004), or back-arc extension over a retreating slab (Schellart et al., 2006; Sutherland et al., 2010). Because continental fragments and microcontinents are formed during extensional processes, it is likely they are bound by deep crustal detachment faults and are thinned from normal faulting (Peron-Pinvidic and Manatschal, 2010; Reston, 2011). The continental fragments of the southwest Pacific ocean are formed in a back-arc extensional regime and are thus bounded by back-arc basins similar to those of island arcs in the Pacific.

\subsection{Continental fragments and microcontinents: crustal structure}

Naturally, continental fragments and microcontinents have crustal compositions similar to those of typical continental crust. In general, seismic studies have identified two crustal layers with low seismic velocity values representative of their continental affinity. However, the rifting processes that led to the formation of continental fragments and microcontinents most likely affect their layers and entire thicknesses (Morewood et al., 2005), as well as adding mafic intrusions to the crust. From 36 geophysical studies of continental fragments we determine an average crustal thickness of $\sim 24.8 \pm 5.7 \mathrm{~km}$ (Table 5). Continental fragments have a sediment layer that can be up to $5 \mathrm{~km}$ thick and overlying two to three crustal layers, some of which are underplated with a mafic layer (Fig. 8). The thick sedimentary layer is generally devoid of volcanics, but some rift-related sills may intrude the sedimentary sequences of continental fragments in regions of high magmatism (Richardson et al., 1999; Davison et al., 2010). The upper crust has seismic velocities around $5.5 \mathrm{~km} \mathrm{~s}^{-1}$, most likely from rocks of granitic and gneissic composition. The seismic velocities of the mid-crustal layer range from 6.0 to $6.5 \mathrm{~km} \mathrm{~s}^{-1}$. The lower crust typically has velocities of $6.5-7.0 \mathrm{~km} \mathrm{~s}^{-1}$ and is inferred to be gabbroic. In only a few continental fragments, a basal layer with high seismic velocities $\left(7.4-7.8 \mathrm{~km} \mathrm{~s}^{-1}\right)$ is found above the seismic Moho (Fig. 8). The high velocity layer under the Faroe Bank is interpreted to be a layer of mafic sill intrusions in the crust related to the Iceland plume or convective upwellings (Harland et al., 2009). Under the Rockall Bank, this layer is believed to be serpentinized upper mantle (O'Reilly et al., 1996). For the continental fragments off the Australian margin, the high velocity lower layer is interpreted as mafic underplating (Grobys et al., 2009). Mostly, the high velocity seismic layer is found below the surrounding basins with oceanic or thinned continental crust. In these regions, the high velocity layer is also hypothesized to be either serpentinized mantle or mafic underplating (O'Reilly et al., 1996; Reston et al., 2001; Lundin and Doré, 2011).
The average crustal density of continental fragments and microcontinents, determined with the Christensen and Mooney (1995) depth-dependent relationship from seismic velocities from 20 studies, is $\sim 2.81 \mathrm{~g} \mathrm{~cm}^{-3}$ (Table 6). As we expect, the average crustal density of continental fragments and microcontinents is similar to that of the typical continental crust. Despite having thicknesses much lower than the average continental crust ( $25 \mathrm{~km}$ compared to $41 \mathrm{~km}$ ) the lower densities calculated because of the smaller depths $(<25 \mathrm{~km})$ are balanced by the mafic underplating contribution to several of the continental fragments. Interestingly, the average crustal density determined from the eight seismic studies that constrained their models with gravity measurements is a lower value of $2.79 \mathrm{~g} \mathrm{~cm}^{-3}$. The lower densities derived by gravity modeling are mainly from studies on continental fragments with no seismically identified mafic basal layer.

\subsection{Continental fragments and microcontinents: accreted examples}

Because the classification and the identification of how such features form offshore of passive margins is relatively new (Peron-Pinvidic and Manatschal, 2010, see references therein), there has been little recognition of such features in the accretionary record. The most recognized accreted continental crustal units are found in the Alps. Many of the crustal units accreted in the Alps are believed to be rifted continent fragments (Manatschal, 2004), such as the Briançonnais terrane (Handy et al., 2010), gneiss units of the Piemonte units (Beltrando et al., 2010), and the Monte Rosa nappe (Froitzheim, 2001). In Newfoundland, the Dashwoods terrane is interpreted to be a rifted microcontinent block on the passive margin of Laurentia that was later reunited with Laurentia during the Taconic orogeny (Waldron and van Staal, 2001).

Accretionary and collisional processes could utilize the underlying detachment faults or surrounding exhumed and serpentinized mantle lithosphere. There is evidence for detachment faults that are inherited from initial rifting on the Briançonnais terrane and other accreted continental fragments (Reston, 2011). In western Norway, mantle peridotite melange units, reinterpreted as hyperextended crust, underlie accreted microcontinent slivers of Gula, Jotunn, and Lindas nappes (Andersen et al., 2012). Precambrian terranes with continental affinities (gneisses) of the Central Asian Orogenic belt are bound by ophiolitic sutures and interpreted as microcontinents rifted off of the East Gondwana margin (Windley et al., 2007). It is possible that the ophiolites (characterized by sedimentary units, volcanics, and deep marine formations; Windley et al., 2007) bounding these continental terranes are hyperextended crust.

Modern analogues of continental fragment accretion exist in Southeast Asia, where many continental fragments were created during back-arc basin rifting. In this region, continental fragments are accreting and colliding with arcs and 


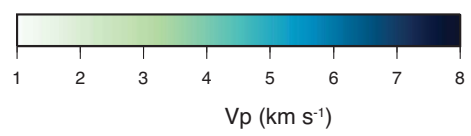

Continental fragments and microcontinents
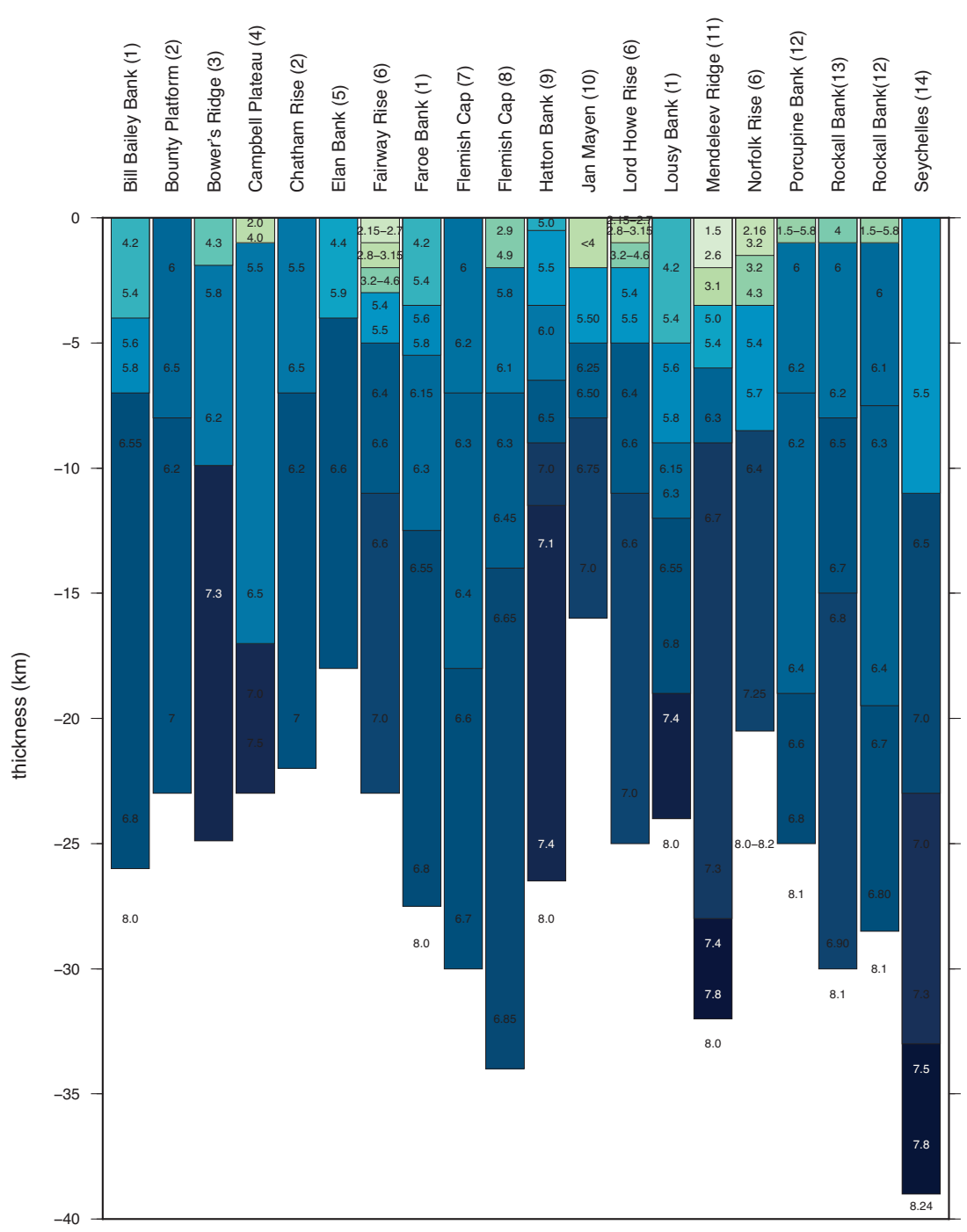

Figure 8. Seismic velocity profiles of modern continental fragments. References are (1) Funck et al. (2008), (2) Grobys et al. (2007), (3) Cooper et al. (1981), (4) Grobys et al. (2009), (5) Borissova et al. (2003), (6) Klingelhoefer et al. (2007), (7) Funck (2003), (8) Gerlings et al. (2011), (9) Fowler et al. (1989), (10) Breivik et al. (2012), (11) Lebedeva-Ivanova et al. (2006), (12) Morewood et al. (2005), (13) Vogt et al. (1998), and (14) Collier et al. (2009).

other continental fragments. The North Palawan block is the best example of a passive margin fragment currently impinging on an island arc (the Philippine Mobile Belt). The North Palawan block rifted off of the China margin during the extensional opening of the South China Sea (Bird et al., 1993) and is colliding with the Philippine continental arc (Yumul et al., 2009). Other continental fragments, such as the Sulawesi block and the Bird's Head block, were created during back-arc rifting events and are now sutured to basin blocks in the present Sunda continental arc (Pubellier et al., 2003, 2004).

\section{Composite terranes}

Often it is the case that FATs will combine before accreting onto a continent - such as oceanic plateau-island arc 
Table 5. Crustal thicknesses of continental fragments from seismic studies unless otherwise noted.

\begin{tabular}{|c|c|c|}
\hline $\begin{array}{l}\text { Continental fragments } \\
\text { and microcontinents }\end{array}$ & Thickness (km) & Reference \\
\hline Alpha-Mendeleev & 26 & Lebedeva-Ivanova et al. (2011) \\
\hline Bill Bailey Bank & 26 & Funck et al. (2008) \\
\hline Bounty Platform & 23 & Grobys et al. (2007) \\
\hline Bower's Ridge & 25 & Cooper et al. (1981) \\
\hline Campbell plateau & 24 & Grobys et al. (2009) \\
\hline Chatham Rise & 22 & Grobys et al. (2007) \\
\hline Chatham Rise & 20 & gravity modeling: Davy et al. (2008) \\
\hline East Greenland Ridge & $9-11$ & Døssing et al. (2008) \\
\hline Elan Bank & 16 & Borissova et al. (2003) \\
\hline Exmouth Plateau & 20 & magnetotellurics: Heinson (2005) \\
\hline Fairway Ridge & 23 & Klingelhoefer et al. (2007) \\
\hline Falkland plateau & $25-30$ & gravity modeling: Kimbell and Richards (2008) \\
\hline Faroe Bank & 27.5 & Funck et al. (2008) \\
\hline Faroe Islands & $35-40$ & Richardson et al. (1999) \\
\hline Flemish Cap & 33 & Gerlings et al. (2011) \\
\hline Flemish Cap & 30 & Funck (2003) \\
\hline Galicia Bank & 22 & González et al. (1999) \\
\hline Hatton Bank & 26.5 & Fowler et al. (1989) \\
\hline Hatton Bank & 23 & White and Smith (2009) \\
\hline Jan Mayen & 16 & Breivik et al. (2012) \\
\hline Jan Mayen & 19 & Kodaira et al. (1998) \\
\hline Lomonosov Ridge & 26 & Jackson et al. (2010) \\
\hline Lomonosov Ridge & 26 & Poselov et al. (2003) \\
\hline Lord Howe Rise & 25 & Klingelhoefer et al. (2007) \\
\hline Lord Howe Rise & 29 & Shor et al. (1971) \\
\hline Lousy Bank & 24 & Funck et al. (2008) \\
\hline Lousy Bank & 25 & Klingelhoefer et al. (2005) \\
\hline Mendeleev Ridge & 32 & Lebedeva-Ivanova et al. (2006) \\
\hline Norfolk rise & 205 & Klingelhoefer et al. (2007) \\
\hline Norfolk rise & 21.6 & Shor et al. (1971) \\
\hline Porcupine Bank & 28 & Whitmarsh et al. (1974) \\
\hline Porcupine Bank & 25 & Morewood et al. (2005) \\
\hline Rockall Bank & 30 & Vogt et al. (1998) \\
\hline Rockall Bank & 28.5 & Morewood et al. (2005) \\
\hline Sao Paolo Plateau & $12-16$ & gravity modeling: Scotchman et al. (2010) \\
\hline Seychelles & 39 & Collier et al. (2009) \\
\hline Average & $24.8 \pm 5.7$ & \\
\hline
\end{tabular}

compositeterranes. In general, the larger mass of these FATs makes accretion by collision inevitable. The currently accreting Yakutat terrane in Alaska has been speculated to be a continental-oceanic composite terrane. Parts of the Yakutat subducting under Alaska involve oceanic basement or oceanic plateau crust, while the accreting eastern region of the crust is of continental composition (Bruhn et al., 2004).

Modern examples of composite terranes include arcarc collisions, arc-oceanic plateau collisions, and arccontinental fragment collisions. The formation of composite terranes is widely observed in Southeast Asia where numerous island arcs and continental fragments are actively subducting and accreting (Hall, 2009; Pubellier and Mer- esse, 2013). On the Philippine Sea Plate, the Halmahera and Sangihe arcs are colliding with doubly verging subduction zones and closing the Molucca sea (Pubellier et al., 1999). Another example of arc-arc collision is in central Japan, where the Izu arc collides and underplates the Honshu arc (Arai et al., 2009). Arc-submarine ridge collision is observed with the subduction of the Ogasawara plateau under the IzuBonin arc (Miura et al., 2004a). And the active collision of the Ontong Java oceanic plateau with the Solomon arc (Petterson et al., 1997; Mann and Taira, 2004) represents a modern analog to the accreted Yakutat-Wrangellia terrane in North America. 
Table 6. Bulk densities $\left(\mathrm{g} \mathrm{cm}^{-3}\right)$ of continental fragments and microcontinents determined from seismic velocities using various velocitydensity curves. Bulk densities are also reported from studies where the authors combined gravity and seismic data to determine crustal density. References are (1) Funck et al. (2008), (2) Grobys et al. (2007), (3) Cooper et al. (1981), (4) Grobys et al. (2009), (5) Borissova et al. (2003), (6) Klingelhoefer et al. (2007), (7) Funck (2003), (8) Gerlings et al. (2011), (9) Fowler et al. (1989), (10) Breivik et al. (2012), (11) Lebedeva-Ivanova et al. (2006), (12) Morewood et al. (2005), (13) Vogt et al. (1998), and (14) Collier et al. (2009).

\begin{tabular}{lllll}
\hline $\begin{array}{l}\text { Continental fragments } \\
\text { and microcontinents }\end{array}$ & $\begin{array}{l}\text { Nafe- } \\
\text { Drake }\end{array}$ & $\begin{array}{l}\text { Christensen- } \\
\text { Mooney }\end{array}$ & $\begin{array}{l}\text { Christensen- } \\
\text { Shaw }\end{array}$ & $\begin{array}{l}\text { Reported in } \\
\text { the study }\end{array}$ \\
\hline Bill Bailey Bank $^{1}$ & 2.80 & 2.81 & 2.78 & 2.79 \\
Bounty Platform $^{2}$ & 2.83 & 2.86 & 2.87 & \\
Bower's Ridge $^{3}$ & 2.90 & 2.92 & 2.93 & \\
Campbell Plateau $^{4}$ & 2.78 & 2.79 & 2.75 & \\
Chatham Rise $^{2}$ & 2.82 & 2.83 & 2.85 & \\
Elan Bank $^{5}$ & 2.82 & 2.85 & 2.84 & \\
Fairway Rise $^{6}$ & 2.78 & 2.77 & 2.72 & 2.74 \\
Faroe Bank $^{1}$ & 2.79 & 2.81 & 2.77 & 2.77 \\
Flemish Cap $^{7}$ & 2.82 & 2.85 & 2.83 & \\
Flemish Cap $^{8}$ & 2.81 & 2.83 & 2.85 & \\
Hatton Bank $^{9}$ & 2.92 & 2.96 & 2.98 & \\
Jan Mayen $^{10}$ & 2.75 & 2.69 & 2.74 & 2.77 \\
Lord Howe Rise $^{6}$ & 2.81 & 2.82 & 2.79 & 2.79 \\
Lousy Bank $^{1}$ & 2.79 & 2.79 & 2.76 & \\
Mendeleev Ridge $^{11}$ & 2.84 & 2.85 & 2.82 & 2.77 \\
Norfolk Rise $^{6}$ & 2.74 & 2.71 & 2.64 & \\
Porcupine Bank $^{12}$ & 2.76 & 2.75 & 2.79 & 2.83 \\
Rockall Bank $^{13}$ & 2.85 & 2.88 & 2.89 & \\
Rockall Bank $^{12}$ & 2.79 & 2.80 & 2.82 & 2.86 \\
Seychelles $^{14}$ & 2.89 & 2.94 & 2.92 & \\
\hline Average & $2.82 \pm 0.05$ & $2.81 \pm 0.08$ & $2.83 \pm 0.06$ & $2.79 \pm 04$ \\
\hline
\end{tabular}

In the geological record, large volumes of crustal accretion are carried out by the collision of composite terranes or continental fragments onto continents (Vink et al., 1984). In North America, the amalgamation of the Wrangellia and Stikinia terranes resulted in a ribbon continent (SABIYA) that was $\sim 8000 \mathrm{~km}$ long and $\sim 500 \mathrm{~km}$ wide (Johnston, 2001). During the collision of the superterrane with North America, the mantle lithosphere belonging to the microcontinent was also sutured to the continent, as evidenced by seismic reflection lines (Hammer et al., 2010) and mantle xenoliths from both regions (Johnston, 2008). Another notable accreted ribbon composite terranes is the Cimmerian superterrane which closed the Tethyan sea (Sengor, 1979).

\section{Discussion}

\subsection{FAT similarities and differences}

This review of the crustal composition of future accreted terranes highlights the variability in crustal thickness and structure between FAT groups as well as within each group. A comparison of modern FATs to their accreted versions can help us understand crustal composition of accreted units, the amount of crust lost during subduction, and the processes that allow for accretion and collision. Based on average crustal thickness and density, there appears to be no significant difference between FAT groups that would indicate that one particular group would be more susceptible to subduction or accretion. The seismic velocity profiles from each of the three FAT groups show considerable overlap with the average continental crust given by Christensen and Mooney (1995) (Fig. 9). However, all three groups show considerable variability in their crustal structure, depending on their formation and tectonic history, and this will play a part in terrane accretion.

The crustal structure of island arcs is composed of two to three layers which are commonly underlain by ultramafic cumulates (the CMTL). The main differences in arc crustal composition and thickness are products of maturation: juvenile arcs are more mafic, thinner, and smaller, while mature island arcs have undergone repetitive anatexis to produce a felsic middle layer. The ultramafic cumulate layer found in most arcs could be formed during early anatexis of the initial basaltic island arc crust (Tatsumi et al., 2008). Foundering of this subcrustal ultramafic layer on mature island arcs would leave a crustal composition that is intermediatecomposition 

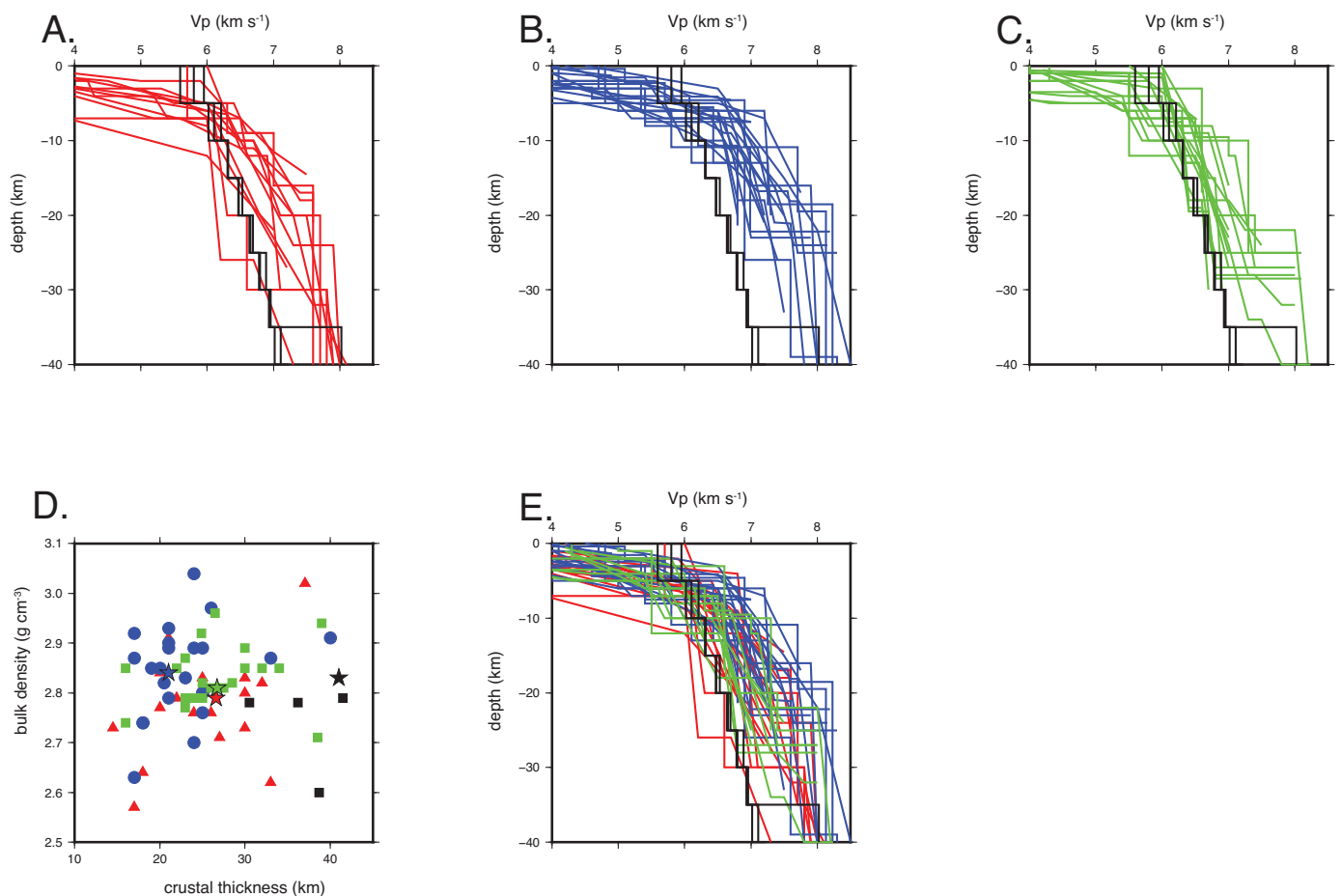

Figure 9. (a) Velocity profiles for island arcs (red), (b) oceanic LIPs (blue), (c) continental fragments (green) compared to the average velocity profiles of continental crust (black) from Christensen and Mooney (1995). (d) Bulk crustal density versus crustal thickness for oceanic plateaus (blue circles), island arcs (red triangles), continental fragments (green squares) and continental crust (black squares). Average values for FATs and continental crust are plotted as stars. All densities are converted from seismic velocities using the relationships in Christensen and Mooney (1995). (e) Velocity profiles for all FATs plotted together.

and a better contributor to the continental crust. However, many accreted terranes from island arcs do contain units from the ultramafic CMTL, so further modification needs to occur to produce a more compositionally similar crust to continents, such as by the addition of adakites from postcollision magmatism and melting of the continental lower crust (Chung et al., 2003).

Oceanic plateaus and submarine ridges are quite varied in their crustal structure, and some are also underlain by a high seismic velocity layer. Moreover, recognized oceanic plateaus do not have unique seismic crustal structures or thicknesses which can be differentiated from submarine ridges (Fig. 6). To determine whether a large mafic igneous feature on the ocean floor is an oceanic plateau or submarine ridge, the geochemical and geodynamic history is obviously needed. Accreted mafic terranes, typically greenstone belts, represent oceanic plateaus, submarine ridges, and seamounts that have been added to continents by accretion or collision. The large terranes ( $>30 \mathrm{~km}$ thick) of Wrangellia and Siletz in North America indicate that these mafic bodies are significant contributors to continental crust despite their mafic composition. Indeed, Archeaen greenstone belts have led some researchers to suggest that accreted oceanic plateaus were the major crustal contributor in the Precambrian (e.g., Puchtel et al., 1998; Desrochers et al., 1993).
However, more recent (Paleozoic) tectonic growth of continents is believed to be from felsic island arcs or modified post-accretion oceanic plateaus (Clift et al., 2009b, a; Stern and Scholl, 2010).) There is observational evidence for modern day subduction of oceanic plateaus and submarine ridges: the Hikurangi oceanic plateau subducting seemingly intact to approximately $65 \mathrm{~km}$ depth under New Zealand (Reyners et al., 2006), the Ontong Java Plateau subducting under the Solomon Islands (Mann and Taira, 2004), and the Nazca Ridge under Peru (Hampel et al., 2004). In these instances, units from the sedimentary and upper crustal layers are being actively scraped off at the accretionary prism (Mann and Taira, 2004) or underplated at the plate interface (ContrerasReyes and Carrizo, 2011), leaving behind evidence of the oceanic plateau's existence after subduction.

Being rifted off fragments of continental crust, continental fragments have crustal compositions similar to continental crust. The accretion of continental fragments or microcontinents does not require post-accretion modification to achieve the average composition of continental crust. The main difference between the crustal structure of continental fragments and that of typical continental crust is the magmatic addition from extension and rifting that leads to the formation of continental fragments. Because of their geographic relation to continents (as part of the passive margin 
architecture), continental fragments will most likely precede continents into the subduction zone and continent-continent collision. But not all continental crust will accrete; the subductability of continental crust has been proven by coesite found in exhumed ultrahigh pressure terranes (Chopin, 2003) and geodynamic modeling (Afonso and Zlotnik, 2011). The collision of continental fragments with continents can lead to slab detachment and then exhumation of these continentally derived terranes.

In terms of seismic crustal structure, there is too much variation within and between groups to determine whether a crustal profile belongs to an island arc, oceanic plateau and submarine ridge, or continental fragment (Fig. 9e). While the seismic velocity profiles of continental fragments do appear to best match the average continental crust profile, there is significant overlap between the velocity profiles of continental fragments and oceanic plateaus/submarine ridges (Fig. 9). Clearly, seismic velocity profiles should not be the sole basis for determining the nature of crustal composition of an unclassified region of anomalous crust on the ocean floor. One example is the recent finding of granite in deep sea drilling of Rio Grande Rise that would reclassify that feature as a continental fragment rather than a submarine ridge (Corfield, 2013). We would argue that combining gravity measurements with seismic models can narrow the origin of an undetermined FAT crust, as also suggested by Barton (1986) for calculating densities directly from seismic values. Many regions of anomalous crust on the Arctic ocean floor have been identified as both continental fragments and oceanic plateaus because of the low constraints provided by only using seismic velocities to determine the crustal composition (Dove et al., 2010; Lebedeva-Ivanova et al., 2006; Artyushkov, 2010). When determining the true crustal nature, seismic, gravity, and geochemical studies should also be reinforced with tectonic reconstructions to gain insight on the geological history of an unknown FAT.

\subsection{From FAT to accreted terrane}

Accretionary orogens are built of accreted terranes that are hundreds of meters thick, characterized by thin-skinned deformation, and suture bound. In terranes where units from the entire crust of island arcs and oceanic LIPs are preserved, the remaining crustal thickness has been severely sheared and thinned. Although buoyancy is an enabling factor in crustal accretion at subduction zones, it is likely that accretion can occur because weak layers in the FAT crust enable detachments and shear zones to develop within the subduction zone as the crust is subducting. Recent geodynamic experiments show that if a weak zone or detachment fault is present within the crust of the subducting crustal region, whether it is an island arc, oceanic plateau, or continental fragment, accretion will occur and leave a severely thinned terrane (Afonso and Zlotnik, 2011; Tetreault and Buiter, 2012). In island arcs, possible delamination units are the felsic middle crust and the CMTL. Pre-existing weaknesses in island arcs produced by back-arc rifting can also serve as detachment faults during subduction. Another important factor in tectonic accretion of island arcs to continents is the elevated geotherm resulting in more buoyant crust and mantle (Cloos, 1993). For example, the Moho temperature for the accreted Talkeetna arc is estimated to be around $900^{\circ} \mathrm{C}$ (Hacker et al., 2008), which is comparable to cold island arc systems but much higher than typical continental Moho temperatures. Active island arcs will have hot and thin lithospheres, and the high geotherms could activate detachments between crustal layers. The depth of the weak layer or detachment determines the amount of crust and the layers of crust that can be underplated (Tetreault and Buiter, 2012). Continental fragments also may contain pre-existing faults from their earlier rifting stage that could serve as detachment faults during subduction. And while there is no observed evidence for delamination of the ultramafic layer underplating oceanic plateaus, we infer that this layer could also act similar to the ultramafic layer found in island arcs and serve as a décollement during accretion. Collision and docking of large FATs can lead to a small jump in the location of the subduction interface as the slab tears from the accreted terrane, creating asthenospheric upwelling and post-collision magmatism (Pubellier and Meresse, 2013).

The crustal deficit of most accreted island arcs, oceanic plateaus, submarine ridges, continental fragments, and even seamounts suggests that a significant amount of crustal material is recycled back into the mantle. Perhaps the foundering of the lower crust and CMTL of oceanic plateaus and island arcs, which is considered to be a major mechanism of terrane accretion, can account for the volumetric loss of crustal material (Stern and Scholl, 2010). Whether the ultramafic unit below the lower crust in many FATs is dense enough to create instability and delamination can be determined from laboratory studies of accreted ultramafic units. The ultramafic cumulates of the CMTL in island arcs are inferred to have higher densities than upper mantle dunites when calculated with the expected temperatures and pressures at lower crustal depths (Behn and Kelemen, 2006). Results from seismic anisotropy studies and crystal fractionation modeling of arc crustal magma development support the theory that the ultramafic high velocity layer under island arcs is often delaminated before or during accretion. In the accreted Wrangellia oceanic plateau, seismic refraction studies of the crust do not show any high $P$ wave velocities (Brennan et al., 2011; Ramachandran et al., 2006), which can be interpreted as loss of the ultramafic subcrustal layer. However, interestingly enough, combined gravity and seismic studies of modern island arcs, oceanic plateaus, and submarine ridges do not involve a high density unit between the crust and mantle (Larter et al., 2003; Grow, 1973; Magnani et al., 2009; Christeson et al., 2008; Gohl and UenzelmannNeben, 2001; Sallares et al., 2003; Recq et al., 1998; Walther, 2003; Sinha et al., 1981; Peirce and Barton, 1991; Hampel 
et al., 2004; Shulgin et al., 2011; Patriat et al., 2002), contrary to the laboratory-derived densities of the arc CMTL rocks. In addition, the ultramafic units below the lower crust could be a rheologically weak layer that leads to décollement-related underplating during subduction.

Post-collision magmatism can alter the composition of accreted terranes by introducing melt from the lower crust and mantle. Transitional I-S-type granites in the Sibumasa terrane of Malaysia were emplaced post-collision and indicate that melting of the lower crust occurred with additional mantle heat (Ghani et al., 2013). Post-collision, slab detachment led to asthenospheric upwelling and partial melting of the thickened crust to produce granitoids in the Meguma Terrane of Nova Scotia (Keppie and Dallmeyer, 1995). Similarly, recent geochemical work on the plutons of the Barnard Glacier suite predicts it was formed due to asthenospheric upwelling from slab detachment after Wrangellia collided with the Alexander composite terrane (Beranek et al., 2014). These magmatic sutures help to modify the accreted terrane crust.

Besides the crustal features of FATs, other factors that may influence terrane accretion are the thickness of the subduction zone interface, whether the subduction zone is accretionary or erosive, and slab pull forces. Numerical experiments have shown that a thin subduction interface will promote shearing of the FAT crust and accretion of the upper crustal layers (De Franco et al., 2008). The nature of the accretionary prism region can be either erosive or accretionary depending on the convergence rates and sedimentary and erosive fluxes (Clift and Vannucchi, 2004; Scholl and von Huene, 2010), and this will factor into whether crust is recycled back into the mantle or not. Finally, the force of the subducting slab drives subduction and can most likely overcome the buoyancy of small crustal units (Molnar and Gray, 1979; Cloos, 1993). In addition, eclogitization of the oceanic lithosphere will increase the negative buoyancy of the slab and even allow continental crust to subduct (Afonso and Zlotnik, 2011).

Another option for loss of ultramafic lower crustal material could be removal by back-arc mantle convection. Smallscale mantle convection in the back-arc region could contribute to lower crustal flow and crustal and lithospheric thinning in a continental back-arc mobile belt (Hyndman et al., 2005). Back-arc extension on an oceanic plate leads to remnant island arcs, and the elevated mantle temperatures will lead to more vigorous small convection that can easily aid in the removal of the CMTL layer in remnant arcs and active arcs. Numerical experiments have shown that small scale convection under continental back-arcs (Currie and Hyndman, 2006) and oceanic back-arcs (Honda and Saito, 2003) is necessary to fit heat flow measurements, low viscosity layers under back-arcs, and seismic anisotropy observations. Indeed, small scale convection under the Izu-Bonin Arc, as inferred by the spatial and temporal patterns of volcanic activity (Honda et al., 2007), would aid in removal of the CMTL layers under the Izu, Bonin, and Mariana, active island arcs and their remnant arcs.

\section{Conclusions}

Regions of high topography and anomalous crust on the oceanic floor that encounter an active subduction zone are likely to become accreted terranes. These future allochthonous terranes include island arcs, oceanic plateaus, submarine ridges, seamounts, continental fragments, and microcontinents. By comparing modern FATs to examples of accreted terranes, we can better constrain the quantities of crust that are subducted and the material parameters that contribute to accretion. We find that modern island arcs have an average crustal thickness of $26 \mathrm{~km}$, oceanic plateaus and submarine ridges have an average thickness of $21 \mathrm{~km}$, and continental fragments and microcontinents have an average crustal thickness of $25 \mathrm{~km}$. Yet most accreted terranes of island arc, oceanic plateau, submarine ridge, seamount, and continental fragment affinity are on the order of meters to kilometers thick. In the cases where collision occurred rather than accretion by underplating or scraping into the accretionary prism, accreted terranes are interpreted to be 25 $40 \mathrm{~km}$ thick. The average crustal densities for island arcs is $2.79 \mathrm{~g} \mathrm{~cm}^{-3}, 2.84 \mathrm{~g} \mathrm{~cm}^{-3}$ for oceanic plateaus and submarine ridges, and $2.81 \mathrm{~g} \mathrm{~cm}^{-3}$ for continental fragments and microcontinents.

The different crustal structures of these FATs and their rheological differences can lead to various processes of accretion, including accretionary prism thrusting, underplating, and collision. Crustal slivers of island arcs typically underplate and accrete to the overriding continent. Subduction of oceanic plateaus and submarine ridges often leads to accretion by collision. Seamounts and submarine volcanics subduct easily if they are not incorporated into the accretionary prism. Continental fragments likely lead to collision rather than accretion via underplating as they are connected to passive margins. In addition to the buoyancy of FAT crust, weak crustal layers and delamination of the lower crust and subcrustal layers lead to accretion and formation of accreted terranes.

Acknowledgements. This study was supported by the Norwegian Research Council through NFR project 180449. Figures 1-8 were constructed with GMT software (Wessel and Smith, 1991). This paper was improved by the insightful comments and reviews from William Collins and Manuel Pubellier. We also thank the reviews of an anonymous reviewer and Andrew Kerr on a previous iteration of this manuscript.

Edited by: F. Rossetti 


\section{References}

Afonso, J. C. and Zlotnik, S.: The subductability of continental lithosphere: The before and after story, in: Arc-Continent Collision, edited by: Brown, D. and Ryan, P., Front. Earth Sci., 53-86, 2011.

Amante, C. and Eakins, B.: ETOPO1 1 Arc-Minute Global Relief Model: Procedures, Data Sources and Analysis, NOAA Technical Memorandum NESDIS NGDC-24, National Geophysical Data Center, NOAA, 2009.

Andersen, T. B., Corfu, F., Labrousse, L., and Osmundsen, P.-T.: Evidence for hyperextension along the pre-Caledonian margin of Baltica, J. Geol. Soc., 169, 601-612, 2012.

Arai, R., Iwasaki, T., Sato, H., Abe, S., and Hirata, N.: Collision and subduction structure of the Izu-Bonin arc, central Japan, revealed by refraction/wide-angle reflection analysis, Tectonophysics, 475, 438-453, 2009.

Artyushkov, E.: Continental crust in the Lomonosov Ridge, Mendeleev Ridge, and the Makarov basin. The formation of deep-water basins in the Neogene, Russ. Geol. Geophys., 51, 1179-1191, 2010.

Barton, P. J.: The relationship between seismic velocity and density in the continental crust - a useful constraint?, Geophys. J. R. astr. Soc., 87, 195-208, 1986.

Bassett, D., Sutherland, R., Henry, S., Stern, T., Scherwath, M., Benson, A., Toulmin, S., and Henderson, M.: Three-dimensional velocity structure of the northern Hikurangi margin, Raukumara, New Zealand: Implications for the growth of continental crust by subduction erosion and tectonic underplating, Geochem. Geophys. Geosyst., 11, 10, doi:10.1029/2010GC003137, 2010.

Behn, M. D. and Kelemen, P. B.: Stability of arc lower crust: Insights from the Talkeetna arc section, south central Alaska, and the seismic structure of modern arcs, J. Geophys. Res., 111, B11207, doi:10.1029/2006JB004327, 2006.

Behn, M. D., Hirth, G., and Kelemen, P. B.: Trench-Parallel Anisotropy Produced by Foundering of Arc Lower Crust, Science, 317, 108-110, 2007.

Beltrando, M., Rubatto, D., and Manatschal, G.: From passive margins to orogens: The link between ocean-continent transition zones and (ultra)high-pressure metamorphism, Geology, 38, 559-562, 2010.

Ben-Avraham, Z., Nur, A., Jones, D., and Cox, A.: Continental Accretion: From Oceanic Plateaus to Allochthonous Terranes, Science, 213, 47-54, 1981.

Beranek, L. P., van Staal, C. R., McClelland, W. C., Joyce, N., and Israel, S.: Late Paleozoic assembly of the Alexander-WrangelliaPeninsular composite terrane, Canadian and Alaskan Cordillera, Geol. Soc. Am. Bull., 26, 1531-1550, doi:10.1130/31066.1, 2014.

Bird, P., Quinton, N., Beeson, M., and Bristow, C.: Mindoro: a rifted microcontinent in collision with the Philippines volcanic arc; basin evolution and hydrocarbon potential, J. Southe. Asian Earth, 8, 449-468, 1993.

Bohnhoff, M. and Makris, J.: Crustal structure of the southeastern Iceland-Faeroe Ridge (IFR) from wide aperture seismic data, J. Geodyn., 37, 233-252, 2004.

Borissova, I., Coffin, M. F., Charvis, P., and Operto, S.: Structure and development of a microcontinent: Elan Bank in the southern Indian Ocean, Geochem. Geophys. Geosyst., 4, 9, doi:10.1029/2003GC000535, 2003.
Boutelier, D., Chemenda, A., and Burg, J.-P.: Subduction versus accretion of intra-oceanic volcanic arcs: insight from thermomechanical analogue experiments, Earth Planet. Sci. Lett., 212, 31-45, 2003.

Breivik, A. J., Mjelde, R., Faleide, J. I., and Murai, Y.: The eastern Jan Mayen microcontinent volcanic margin, Geophys. J. Int., 188, 798-818, 2012.

Brennan, P. R. K., Gilbert, H., and Ridgway, K. D.: Crustal structure across the central Alaska Range: Anatomy of a Mesozoic collisional zone, Geochem. Geophys. Geosyst., 12, 4, doi:10.1029/2011GC003519, 2011.

Briais, A., Ondreas, H., Klingelhoefer, F., Dosso, L., Hamelin, C., and Guillou, H.: Origin of volcanism on the flanks of the PacificAntarctic ridge between $41^{\circ} 30^{\prime} \mathrm{S}$ and $52^{\circ} \mathrm{S}$, Geochem. Geophys. Geosyst., 10, doi:10.1029/2008GC002350, 2009.

Bruhn, R. L., Pavlis, T. L., Plafker, G., and Serpa, L.: Deformation during terrane accretion in the Saint Elias orogen, Alaska, Geol. Soc. Am. Bull., 116, 771-787, 2004.

Bryan, S. E. and Ernst, R. E.: Revised definition of Large Igneous Provinces (LIPs), Earth-Sci. Rev., 86, 175-202, 2008.

Bryan, W., Stone, G., and Ewart, A.: Geology, Petrography, and Geochemistry of the Volcanic islands of Tonga, J. Geophys. Res., 77, 1566-1585, 1972.

Buchs, D. M., Baumgartner, P. O., Baumgartner-Mora, C., Bandini, A. N., Jackett, S.-J., Diserens, M.-O., and Stucki, J.: Late Cretaceous to Miocene seamount accretion and melange formation in the Osa and Burica Peninsulas (Southern Costa Rica): episodic growth of a convergent margin, in: The Origin and Evolution of the Caribbean Plate, edited by: James, K., Lorente, M., and Pindell, J., Geol. Soc. Spec. Pub., Geol. Soc. London, 328, 411-456, 2009.

Buck, W. R. and Parmentier, E. M.: Convection Beneath Young Oceanic Lithosphere: Implications for Thermal Structure and Gravity, J. Geophys. Res., 91, 1961-1974, 1986.

Busby, C.: Continental growth at convergent margins facing large ocean basins: a case study from Mesozoic convergent-margin basins of Baja California, Mexico, Tectonophysics, 392, 241277, 2004

Busby, C., Adams, B. F., Mattinson, J., and Deoreo, S.: View of an intact oceanic arc, from surficial to mesozonal levels: Cretaceous Alisitos arc, Baja California, J. Volcanol. Geoth. Res., 149, 1-46, 2006.

Calvert, A. J.: The seismic structure of island arc crust, in: ArcContinent Collision, edited by: Brown, D. and Ryan, P. D., Frontiers in Earth Sciences, Springer Berlin Heidelberg, 4, 87-119, 2011.

Calvert, A. J., Klemperer, S. L., Takahashi, N., and Kerr, B. C.: Three-dimensional crustal structure of the Mariana island arc from seismic tomography, J. Geophys. Res., 113, doi:10.1029/2007JB004939, 2008.

Campbell, I. H. and Kerr, A. C.: The Great Plume Debate: Testing the plume theory, Chem. Geol., 241, 149-152, 2007.

Canil, D., Styan, J., Larocque, J., Bonnet, E., and Kyba, J.: Thickness and composition of the Bonanza arc crustal section, Vancouver Island, Canada, Geol. Soc. Am. Bull., 122, 1094-1105, 2010.

Caress, D. W., McNutt, M. K., Detrick, R. S., and Mutter, J. C.: Seismic imaging of hotspot-related crustal underplating beneath the Marquesas Islands, Nature, 373, 600-603, 1995. 
Carlson, R., Christensen, N. I., and Moore, R.: Anomalous crustal structures in ocean basins: Continental fragments and oceanic plateaus, Earth Planet. Sci. Lett., 51, 171-180, 1980.

Carlson, R. L. and Herrick, C. N.: Densities and porosities in the Oceanic Crust and their variations with depth and age, J. Geophys. Res., 95, 9153-9170, 1990.

Cawood, P. A. and Buchan, C.: Linking accretionary orogenesis with supercontinent assembly, Earth-Sci. Rev., 82, 217-256, 2007.

Cawood, P. A., Kröner, A., Collins, W. J., Kusky, T. M., Mooney, W. D., and Windley, B. F.: Accretionary orogens through Earth history, in: Earth Accretionary Systems in Space and Time, edited by: Cawood, P. A. and Kröner, A., Geol. Soc. Spec. Pub., Geol. Soc. London, 318, 1-36, 2009.

Charvis, P. and Operto, S.: Structure of the Cretaceous Kerguelen Volcanic Province "southern Indian Ocean" from wide-angle seismic data, J. Geodyn., 28, 51-71, 1999.

Charvis, P., Recq, M., Operto, S., and Brefort, D.: Deep structure of the northern Kerguelen Plateau and hotspot-related activity, Geophys. J. Int, 122, 899-924, 1995.

Charvis, P., Laesanpura, A., Gallart, J., Hirn, A., Lepine, J.-C., de Voogd, B., Minshull, T. A., Hello, Y., and Pontoise, B.: Spatial distribution of hotspot material added to the lithosphere under La Reunion, from wide-angle seismic data, J. Geophys. Res., 104, 2875-2893, 1999.

Chave, A. D.: Lithospheric structure of the Walvis Ridge from Rayleigh wave dispersion, J. Geophys. Res., 84, 6840-6848, 1979.

Chopin, C.: Ultrahigh-pressure metamorphism: tracing continental crust into the mantle, Earth Planet. Sci. Lett., 212, 1-14, 2003.

Christensen, N. and Mooney, W.: Seismic velocity structure and composition of the continental crust: A global view, J. Geophys. Res., 100, 9761-9788, 1995.

Christensen, N. I. and Shaw, G. H.: Elasticity of Mafic Rocks from the Mid-Atlantic Ridge, Geophys. J. R. astr. Soc., 20, 271-284, 1970.

Christeson, G. L., Mann, P., Escalona, A., and Aitken, T. J.: Crustal structure of the Caribbean-northeastern South America arc-continent collision zone, J. Geophys. Res., 113, B08104, doi:10.1029/2007JB005373, 2008.

Chung, S.-L., Liu, D., Ji, J., Chu, M.-F., Lee, H.-Y., Wen, D.-J., Lo, C.-H., Lee, T.-Y., Qian, Q., and Zhang, Q.: Adakites from continental collision zones: Melting of thickened lower crust beneath southern Tibet, Geology, 31, 1021-1024, 2003.

Clift, P. and Vannucchi, P.: Controls on tectonic accretion versus erosion in subduction zones: implications for the origin and recycling of the continental crust, Rev. Geophys., 42, 1-31, 2004.

Clift, P. D., Schouten, H., and Vannucchi, P.: Arc-continent collisions, sediment recycling and the maintenance of the continental crust, in: Earth Accretionary Systems in Space and Time, edited by: Cawood, P. A. and Kröner, A., Geol. Soc. Spec. Pub., Geol. Soc. London, 318, 75-103, 2009a.

Clift, P. D., Vannucchi, P., and Morgan, J. P.: Crustal redistribution, crust-mantle recycling and Phanerozoic evolution of the continental crust, Earth-Sci. Rev., 97, 80-104, 2009b.

Cloos, M.: Lithospheric buoyancy and collisional orogenesis: Subduction of oceanic plateaus, continental margins, island arcs, spreading ridges, and seamounts, Geol. Soc. Am. Bull., 105, 715-737, 1993.
Cloos, M. and Shreve, R. L.: Subduction-Channel Model of Prism Accretion, Melange Formation, Sediment Subduction, and Subduction Erosion at Convergent Plate Margins: 1. Background and Description, Pure Appl. Geophys., 128, 455-500, 1988.

Clowes, R. M., Zelt, C. A., Amor, J. R., and Ellis, R. M.: Lithospheric structure in the southern Canadian Cordillera from a network of seismic refraction lines, Can. J. Earth Sci., 32, 14851513, 1995.

Coffin, M. F. and Eldholm, O.: Volcanism and continental break-up: a global compilation of large igneous provinces, in: Magmatism and the Causes of Continental Break-up, edited by: Storey, B., Alabaster, T., and Pankhurst, R., Geol. Soc. Spec. Pub., Geol. Soc. London, 68, 17-30, 1992.

Coffin, M. F. and Eldholm, O.: Large Igneous Provinces: Crustal structure, dimensions, and external consequences, Rev. Geophys., 32, 1-36, 1994.

Collier, J. S., Minshull, T. A., Hammond, J. O. S., Whitmarsh, R. B., Kendall, J.-M., Sansom, V., Lane, C. I., and Rumpker, G.: Factors influencing magmatism during continental breakup: New insights from a wide-angle seismic experiment across the conjugate Seychelles-Indian margins, J. Geophys. Res., 114, B03101, doi:10.1029/2008JB005898, 2009.

Collins, W. J.: Hot orogens, tectonic switching, and creation of continental crust, Geology, 30, 535-538, 2002.

Condie, K. C. and Kröner, A.: The building blocks of continental crust: Evidence for a major change in the tectonic setting of continental growth at the end of the Archean, Gondwana Res., 23, 394-402, 2013.

Coney, P.: Mesozoic-Cenozoic Cordilleran plate tectonics, in: Cenozoic Tectonics and Regional Geophysics of the Western Cordillera, edited by: Smith, R. and Eaton, G., Geol. Soc. A. Mem., Geol. Soc. Am., 152, 33-50, 1978.

Coney, P. J., Jones, D., and Monger, J.: Cordilleran suspect terranes, Nature, 288, 329-333, 1980.

Contreras-Reyes, E. and Carrizo, D.: Control of high oceanic features and subduction channel on earthquake ruptures along the Chile-Peru subduction zone, Phys. Earth Planet, 186, 49-58, 2011.

Contreras-Reyes, E., Grevemeyer, I., Watts, A., Planert, L., Flueh, E., and Peirce, C.: Crustal intrusion beneath the Louisville hotspot track, Earth Planet. Sci. Lett., 289, 323-333, 2010.

Cook, F. A., Clowes, R. M., Snyder, D. B., van der Velden, A. J., Hall, K. W., Erdmer, P., and Evenchick, C. A.: Precambrian crust beneath the Mesozoic northern Canadian Cordillera discovered by Lithoprobe seismic reflection profiling, Tectonics, 23, TC2010, doi:10.1029/2002TC001412, 2004.

Cooper, A. K., Marlow, M. S., and Ben-Avraham, Z.: Multichannel seismic evidence bearing on the origin of Bowers Ridge, Bering Sea, Geol. Soc. Am. Bulletin, 92, 471-484, 1981.

Corfield, R.: Reaching for the real Atlantis, Chemistry and Industry, 77, 36-39, 2013.

Coudert, E., Cardwell, R. K., Isacks, B. L., and Chatelain, J.-L.: $\mathrm{P}$-wave velocity of the uppermost mantle and crustal thickness in the Central Vanuatu Islands (New Hebrides Island arc), Bull. Seis. Soc. Am., 74, 913-924, 1984.

Crawford, W. C., Hildebrand, J. A., Dorman, L. M., Webb, S. C., and Wiens, D. A.: Tonga Ridge and Lau Basin crustal structure from seismic refraction data, J. Geophys. Res., 108, 2195, doi:10.1029/2001JB001435, 2003. 
Currie, C. A. and Hyndman, R. D.: The thermal structure of subduction zone back arcs, J. Geophys. Res., 111, B08404, doi:10.1029/2005JB004024, 2006.

Davison, I., Stasiuk, S., Nuttall, P., and Keane, P.: Sub-basalt hydrocarbon prospectivity in the Rockall, Faroe-Shetland and Møre basins, NE Atlantic, Geol. Soc. London, Petrol. Geol. Conf. series, 7, 1025-1032, 2010.

Davy, B., Hoernle, K., and Werner, R.: Hikurangi Plateau: Crustal structure, rifted formation, and Gondwana subduction history, Geochem. Geophys. Geosyst., 9, 7, doi:10.1029/2007GC001855, 2008.

De Franco, R., Govers, R., and Wortel, R.: Dynamics of continental collision: influence of the plate contact, Geophys. J. Int., 174, 1101-1120, 2008.

Debari, S. M. and Sleep, N. H.: High-Mg, low-Al bulk composition of the Talkeetna island arc, Alaska: Implications for primary magmas and the nature of arc crust, Geol. Soc. Am. Bull., 103, 37-47, 1991.

Den, N., Ludwig, W. J., Murauchi, S., Ewing, J. I., Hotta, H., Edgar, N. T., Yoshii, T., Asanuma, T., Hagiwara, K., Sato, T., and Ando, S.: Seismic-Refraction Measurements in the Northwest Pacific Basin, J. Geophys. Res., 74, 1421-1434, 1969.

Den, N., Ludwig, W., Murauchi, S., Ewing, M., Hotta, H., Asanuma, T., Yoshii, T., Kubotera, A., and Hagiwara, K.: Sediments and Structure of the Eauripik-New Guinea Rise, J. Geophys. Res., 76, 4711-4723, 1971.

Desrochers, J.-P., Hubert, C., Ludden, J. N., and Pilote, P.: Accretion of Archean oceanic plateau fragments in the Abitibi, greenstone belt, Canada, Geology, 21, 451-454, 1993.

Dickinson, W. R.: Geodynamic interpretation of Paleozoic tectonic trends oriented oblique to the Mesozoic Klamath-Sierran continental margin in California, in: Paleozoic and Triassic paleogeography and tectonics of western Nevada and northern California, edited by: Soreghan, M. and Gehrels, G., Geol. Soc. A. SP., Geol. Soc. Am., 347, 209-245, 2000.

Dickinson, W. R.: Geotectonic evolution of the Great Basin, Geosphere, 2, 353-368, 2006.

Dimalanta, C. B. and Yumul, G. P.: Crustal thickening in an active margin setting (Philippines): The whys and the hows, Episodes, 27, 260-264, 2004.

Døssing, A., Dahl-Jensen, T., Thybo, H., Mjelde, R., and Nishimura, Y.: East Greenland Ridge in the North Atlantic Ocean: An integrated geophysical study of a continental sliver in a boundary transform fault setting, J. Geophys. Res., 113, B10107, doi:10.1029/2007JB005536, 2008.

Dove, D., Coakley, B., Hopper, J., Kristoffersen, Y., and Team, H. G.: Bathymetry, controlled source seismic and gravity observations of the Mendeleev ridge; implications for ridge structure, origin, and regional tectonics, Geophys. J. Int., 183, 481-502, 2010.

Draut, A. E. and Clift, P. D.: Differential preservation in the geologic record of intraoceanic arc sedimentary and tectonic processes, Earth-Science Reviews, 116, 57-84, 2013.

Ellis, M.: Lithospheric Strength in Compression: Initiation of Subduction, Flake Tectonics, Foreland Migration of Thrusting, and an Origin of Displaced Terranes, J. Geol., 96, 91-100, 1988.

Ellis, S., Beaumont, C., and Pfiffner, O. A.: Geodynamic models of crustal-scale episodic tectonic accretion and underplating in subduction zones, J. Geophys. Res., 104, 15169-15190, 1999.
England, P., Engdahl, R., and Thatcher, W.: Systematic variation in the depths of slabs beneath arc volcanoes, Geophys. J. Int, 156, 377-408, 2004.

England, P. C. and Katz, R. F.: Melting above the anhydrous solidus controls the location of volcanic arcs, Nature, 467, 700-704, 2010.

English, J. M. and Johnston, S. T.: Collisional orogenesis in the northern Canadian Cordillera: Implications for Cordilleran crustal structure, ophiolite emplacement, continental growth, and the terrane hypothesis, Earth Planet. Sci. Lett., 232, 333-344, 2005.

Espurt, N., Funiciello, F., Martinod, J., Guillaume, B., Regard, V., Faccenna, C., and Brusset, S.: Flat subduction dynamics and deformation of the South American plate: Insights from analog modeling, Tectonics, 27, doi:10.1029/2007TC002175, 2008.

Flower, M. F. J. and Dilek, Y.: Arc-trench rollback and forearc accretion: 1. A collision-induced mantle flow model for Tethyan ophiolites, Geol. Soc. Spec. Pub., 218, 21-41, 2003.

Forsyth, D. W., Harmon, N., Scheirer, D. S., and Duncan, R. A.: Distribution of recent volcanism and the morphology of seamounts and ridges in the GLIMPSE study area: Implications for the lithospheric cracking hypothesis for the origin of intraplate, non-hot spot volcanic chains, J. Geophys. Res., 111, doi:10.1029/2005JB004075, 2006.

Foulger, G. R.: The "plate"model for the genesis of melting anomalies, in: The Origins of Melting Anomalies: Plumes, Plates, and Planetary Processes, edited by: Foulger, G. R. and Jurdy, D., Geol. Soc. A. SP., Geol. Soc. Am., 430, 1-28, 2007.

Fowler, S. R., White, R. S., Spence, G. D., and Westbrook, G. K.: The Hatton Bank continental margin-II. Deep structure from two-ship expanding spread seismic profiles, Geophys. J. Int., 96, 295-309, 1989.

Francis, T. J. and George G. Shor, J.: Seismic refraction measurements in the northwest Indian Ocean, J. Geophys. Res., 71, 427449, 1966.

Francis, T. J. and Raitt, R. W.: Seismic refraction measurements in the southern Indian Ocean, J. Geophys. Res., 72, 3015-3041, 1967.

Frey, F., Coffin, M., Wallace, P., Weis, D., Zhao, X., Jr., S. W., Wahnert, V., Teagle, D., Saccocia, P., Reusch, D., Pringle, M., Nicolaysen, K., Neal, C., Mueller, R., Moore, C., Mahoney, J., Keszthelyi, L., Inokuchi, H., Duncan, R., Delius, H., Damuth, J., Damasceno, D., Coxall, H., Borre, M., Boehm, F., Barling, J., Arndt, N., and Antretter, M.: Origin and evolution of a submarine large igneous province: the Kerguelen Plateau and Broken Ridge, southern Indian Ocean, Earth Planet. Sci. Lett., 176, 7389, 2000.

Froitzheim, N.: Origin of the Monte Rosa nappe in the Pennine Alps-A new working hypothesis, Geol. Soc. Am. Bull., 113, 604-614, 2001.

Funck, T.: Crustal structure of the ocean-continent transition at Flemish Cap: Seismic refraction results, J. Geophys. Res., 108, 2531, doi:10.1029/2003JB002434, 2003.

Funck, T., Andersen, M. S., Neish, J. K., and Dahl-Jensen, T.: A refraction seismic transect from the Faroe Islands to the Hatton-Rockall Basin, J. Geophys. Res., 113, doi:10.1029/2008JB005675, 2008.

Gaina, C., Muller, R., Brown, B., and Ishihara, T.: Microcontinent formation around Australia, in: Evolution and Dynamics of the 
Australian Plate, edited by: Hillis, R. and Muller, R., Geol. Soc. A. SP., Geol. Soc. Am., 372, 405-416, 2003.

Garrido, C. J., Bodinier, J.-L., Dhuime, B., Bosch, D., Chanefo, I., Bruguier, O., Hussain, S. S., Dawood, H., and Burg, J.-P.: Origin of the island arc Moho transition zone via melt-rock reaction and its implications for intracrustal differentiation of island arcs: Evidence from the Jijal complex (Kohistan complex, northern Pakistan), Geology, 35, 683-686, 2007.

Geldmacher, J., Hoernle, K., Bogaard, P. V. D., Hauff, F., and Klugel, A.: Age and Geochemistry of the Central American Forearc Basement (DSDP Leg 67 and 84): Insights into Mesozoic Arc Volcanism and Seamount Accretion on the Fringe of the Caribbean LIP, J. Petrol., 49, 1781-1815, 2008.

Gerlings, J., Louden, K. E., and Jackson, H. R.: Crustal structure of the Flemish Cap Continental Margin (eastern Canada): an analysis of a seismic refraction profile, Geophys. J. Int., 185, 30-48, 2011.

Gettrust, J., Furukawa, K., and Kroenke, L.: Crustal Structure of the Shatsky Rise From Seismic Refraction Measurements, J. Geophys. Res., 85, 5411-5415, 1980.

Ghani, A. A., Searle, M., Robb, L., and Chung, S.-L.: Transitional I S type characteristic in the Main Range Granite, Peninsular Malaysia, J. Asian Earth Sci., 76, 225-240, 2013.

Gohl, K. and Uenzelmann-Neben, G.: The crustal role of the Agulhas Plateau, southwest Indian Ocean: evidence from seismic profiling, Geophys. J. Int., 144, 632-646, 2001.

González, A., Córdoba, D., and Vales, D.: Seismic crustal structure of Galicia Continental Margin, NW Iberian Peninsula, Geophys. Res. Lett., 26, 1061-1064, 1999.

Goslin, J., Recq, M., and Schlich, R.: Structure profonde du plateau de Madagascar: Relations avec le plateau de Crozet, Tectonophysics, 76, 75-85, 89-97, 1981.

Greene, A. R., DeBari, S. M., Kelemen, P., Blusztajn, J., and Clift, P. D.: A Detailed Geochemical Study of Island Arc Crust: the Talkeetna Arc Section, South-Central Alaska, J. Petrol., 47, 1051-1093, 2006.

Greene, A. R., Scoates, J. S., Weis, D., Nixon, G. T., and Kieffer, B.: Melting History and Magmatic Evolution of Basalts and Picrites from the Accreted Wrangellia Oceanic Plateau, Vancouver Island, Canada, J. Petrol., 50, 467-505, 2009.

Greene, A. R., Scoates, J. S., Weis, D., Katvala, E. C., Israel, S., and Nixon, G. T.: The architecture of oceanic plateaus revealed by the volcanic stratigraphy of the accreted Wrangellia oceanic plateau, Geosphere, 6, 47-73, 2010.

Grevemeyer, I. and Flueh, E. R.: Crustal underplating and its implications for subsidence and state of isostasy along the Ninetyeast Ridge hotspot trail, Geophys. J. Int, 142, 643-649, 2000.

Grevemeyer, I., Flueh, E., Reichert, C., Bialas, J., Klaschen, D., and Kopp, C.: Crustal architecture and deep structure of the Ninetyeast Ridge hotspot trail from active-source ocean bottom seismology, Geophys. J. Int., 144, 414-431, 2000.

Grobys, J., Gohl, K., Uenzelmann-Neben, G., Davy, B., and Barker, D.: Extensional and magmatic nature of the Campbell Plateau and Great South Basin from deep crustal studies, Tectonophysics, 472, 213-225, 2009.

Grobys, J. W. G., Gohl, K., Davy, B., Uenzelmann-Neben, G., Deen, T., and Barker, D.: Is the Bounty Trough off eastern New Zealand an aborted rift?, J. Geophys. Res., 112, B03103, doi:10.1029/2005JB004229, 2007.
Grove, T. L., Till, C. B., Lev, E., Chatterjee, N., and Medard, E.: Kinematic variables and water transport control the formation and location of arc volcanoes, Nature, 459, 694-697, 2009.

Grow, J. A.: Crustal and upper mantle structure of the Central Aleutian Arc, Geol. Soc. Am. Bulletin, 84, 2169-2192, 1973.

Gupta, S., Mishra, S., and Rai, S. S.: Magmatic underplating of crust beneath the Laccadive Island, NW Indian Ocean, Geophys. J. Int., 183, 536-542, 2010.

Hacker, B. R., Mehl, L., Kelemen, P. B., Rioux, M., Behn, M. D., and Luffi, P.: Reconstruction of the Talkeetna intraoceanic arc of Alaska through thermobarometry, J. Geophys. Res., 113, B03204, doi:10.1029/2007JB005208, 2008.

Hagen, R. A. and Moberly, R.: Tectonic effects of a subducting aseismic ridge: The subduction of the Nazca Ridge at the Peru Trench, Mar. Geophys. Res., 16, 145-161, 1994.

Hales, A. and Nation, J.: A seismic refraction study in the southern Indian Ocean, Bull. Seis. Soc. Am., 63, 1951-1966, 1973.

Hall, R.: The Eurasian SE Asian margin as a modern example of an accretionary orogen, in: Earth Accretionary Systems in Space and Time, edited by: Cawood, P. A. and Kröner, A., Geol. Soc. Spec. Pub., Geol. Soc. London, 318, 351-372, 2009.

Hammer, P. T., Clowes, R. M., Cook, F. A., van der Velden, A. J., and Vasudevan, K.: The Lithoprobe trans-continental lithospheric cross sections: imaging the internal structure of the North American continent, Can. J. Earth Sci., 47, 821-857, 2010.

Hampel, A., Kukowski, N., Bialas, J., Huebscher, C., and Heinbockel, R.: Ridge subduction at an erosive margin: The collision zone of the Nazca Ridge in southern Peru, J. Geophys. Res., 109, doi:10.1029/2003JB002593, 2004.

Handy, M. R., Schmid, S. M., Bousquet, R., Kissling, E., and Bernoulli, D.: Reconciling plate-tectonic reconstructions of Alpine Tethys with the geological-geophysical record of spreading and subduction in the Alps, Earth-Sci. Rev., 102, 121-158, 2010.

Harland, K. E., White, R. S., and Soosalu, H.: Crustal structure beneath the Faroe Islands from teleseismic receiver functions, Geophys. J. Int., 177, 115-124, 2009.

Hastie, A. R. and Kerr, A. C.: Mantle plume or slab window?: Physical and geochemical constraints on the origin of the Caribbean oceanic plateau, Earth-Sci. Rev., 98, 283-293, 2010.

Heinson, G.: Rifting of a passive margin and development of a lower-crustal detachment zone: Evidence from marine magnetotellurics, Geophys. Res. Lett., 32, L12305, doi:10.1029/2005GL022934, 2005.

Hermansson, T., Stephens, M. B., Corfu, F., Page, L. M., and Andersson, J.: Migratory tectonic switching, western Svecofennian orogen, central Sweden: Constraints from $\mathrm{U} / \mathrm{Pb}$ zircon and titanite geochronology, Precambrian Res., 161, 250-278, 2008.

Hitchen, K.: The geology of the UK HattonRockall margin, Mar. Petrol. Geol., 21, 993-1012, doi:10.1016/j.marpetgeo.2004.05.004, 2004.

Hoernle, K., van den Bogaard, P., Werner, R., Lissinna, B., Hauff, F., Alvarado, G., and Garbe-Schönberg, D.: Missing history (16$71 \mathrm{Ma}$ ) of the Galápagos hotspot: Implications for the tectonic and biological evolution of the Americas, Geology, 30, 795-798, 2002.

Hoernle, K., Hauff, F., van den Bogaard, P., Werner, R., Mortimer, N., Geldmacher, J., Garbe-Schonberg, D., and Davy, B.: Age and geochemistry of volcanic rocks from the Hikurangi and Manihiki 
oceanic plateaus, Geochim. Cosmochim. Ac., 74, 7196-7219, 2010.

Hoffman, P. F. and Ranalli, G.: Archean oceanic flake tectonics, Geophys. Res. Lett., 15, 1077-1080, 1988.

Holbrook, W. S., Lizarralde, D., McGeary, S., Bangs, N., and Diebold, J.: Structure and composition of the Aleutian island arc and implications for continental crustal growth, Geology, 27, 3134, 1999.

Honda, S. and Saito, M.: Small-scale convection under the backarc occurring in the low viscosity wedge, Earth Planet. Sci. Lett., 216, 703-715, 2003.

Honda, S., Yoshida, T., and Aoike, K.: Spatial and temporal evolution of arc volcanism in the northeast Honshu and Izu-Bonin Arcs: Evidence of small-scale convection under the island arc?, Island Arc, 16, 214-223, 2007.

Hussong, D., Wipperman, L., and Kroenke, L.: The Crustal Structure of the Ontong Java and Manihiki Oceanic Plateaus, J. Geophys. Res., 84, 6003-6010, 1979.

Hyndman, R. D., Currie, C. A., and Mazzotti, S. P.: Subduction zone backarcs, mobile belts, and orogenic heat, GSA Today, 15, 4-10, 2005.

Ibrahim, A. K., Pontoise, B., Latham, G., Larue, M., Chen, T., Isacks, B., Recy, J., and Louat, R.: Structure of the New Hebrides Arc-Trench System, J. Geophys. Res., 85, 253-266, 1980.

Ichiyama, Y., Ishiwatari, A., Kimura, J.-I., Senda, R., Kawabata, H., and Tatsumi, Y.: Picrites in central Hokkaido: Evidence of extremely high temperature magmatism in the Late Jurassic ocean recorded in an accreted oceanic plateau, Geology, 40, 411-414, 2012.

Irwin, W. P.: Terranes of the western Paleozoic and Triassic Belt in the southern Klamath Mountains, California, US Geol. Surv. Prof. Paper, 800-C, 103-111, 1972.

Isozaki, Y., Maruyama, S., and Furuoka, F.: Accreted oceanic materials in Japan, Tectonophysics, 181, 179-205, 1990.

Ito, T., Kojima, Y., Kodaira, S., Sato, H., Kaneda, Y., Iwasaki, T., Kurashimo, E., Tsumura, N., Fujiwara, A., Miyauchi, T., Hirata, N., Harder, S., Miller, K., Murata, A., Yamakita, S., Onishi, M., Abe, S., Sato, T., and Ikawa, T.: Crustal structure of southwest Japan, revealed by the integrated seismic experiment Southwest Japan 2002, Tectonophysics, 472, 124-134, 2009.

Jackson, H. R., Dahl-Jensen, T., and the LORITA working group: Sedimentary and crustal structure from the Ellesmere Island and Greenland continental shelves onto the Lomonosov Ridge, Arctic Ocean, Geophys. J. Int., 182, 11-35, 2010.

Johnston, S. and Borel, G.: The odyssey of the Cache Creek terrane, Canadian Cordillera: Implications for accretionary orogens, tectonic setting of Panthalassa, the Pacific superwell, and break-up of Pangea, Earth Planet. Sci. Lett., 253, 415-428, 2007.

Johnston, S. T.: The Great Alaskan Terrane Wreck: reconciliation of paleomagnetic and geological data in the northern Cordillera, Earth Planet. Sci. Lett., 193, 259-272, 2001.

Johnston, S. T.: The Cordilleran Ribbon Continent of North America, Ann. Rev. Earth Planet. Sci, 36, 495-530, 2008.

Jones, D. L., Silberling, N. J., Gilbert, W., and Coney, P.: Character, distribution, and tectonic significance of accretionary terranes in the Central Alaska Range, J. Geophys. Res., 87, 37093717, 1982.

Jull, M. and Kelemen, P. B.: On the conditions for lower crustal convective instability, J. Geophys. Res., 106, 6423-6446, 2001.
Kaneda, K., Nishizawa, A., and Kasahara, J.: Crustal structure model of the Ogasawara Plateau colliding with the Philippine Sea Plate, Japan Earth and Planetary Science Joint Meeting Abstracts, j078-011, 2005.

Kaneda, K., Kodaira, S., Nishizawa, A., Morishita, T., and Takahashi, N.: Structural evolution of preexisting oceanic crust through intraplate igneous activities in the MarcusWake seamount chain, Geochem. Geophys. Geosyst., 11, doi:10.1029/2010GC003231, 2010.

Karig, D. E.: Ridges and Basins of the Tonga-Kermadec Island Arc System, J. Geophys. Res., 75, 239-54, 1970.

Karig, D. E.: Remnant arcs, Geol. Soc. Am. Bull., 83, 1057-1068, 1972.

Keppie, J. D. and Dallmeyer, R. D.: Late Paleozoic collision, delamination, short-lived magmatism, and rapid denudation in the Meguma Terrane (Nova Scotia, Canada): constraints from 40Ar / 39Ar isotopic data, Can. J. Earth Sci., 32, 644-659, 1995.

Kerr, A.: Oceanic Plateaus, in: Treatise on Geochemistry, edited by: Holland, H. D. and Turekian, K. K., Pergamon, Oxford, 537-565, 2003.

Kerr, A. C. and Mahoney, J. J.: Oceanic plateaus: Problematic plumes, potential paradigms, Chem. Geol., 241, 332-353, 2007.

Kerr, A. C. and Tarney, J.: Tectonic evolution of the Caribbean and northwestern South America: The case for accretion of two Late Cretaceous oceanic plateaus, Geology, 33, 269-272, 2005.

Kerr, A. C., Tarney, J., Marriner, G. F., Nivia, A., and Saunders, A. D.: The Caribbean-Colombian Cretaceous Igneous Province: The Internal Anatomy of an Oceanic Plateau, Geoph. Monog. Series, 123-144, 1997.

Kerr, A. C., Tarney, J., Nivia, A., Marriner, G., and Saunders, A.: The internal structure of oceanic plateaus: inferences from obducted Cretaceous terranes in western Colombia and the Caribbean, Tectonophysics, 292, 173-188, 1998.

Kerr, A. C., White, R. V., and Saunders, A. D.: LIP reading: recognizing oceanic plateaux in the geological record, J. Petrol., 41, 1041-1056, 2000.

Kim, H. R., von Frese, R. R. B., Golynsky, A. V., Taylor, P. T., and Kim, J. W.: Crustal analysis of Maud Rise from combined satellite and near-surface magnetic survey data, Earth Planet. Space, 57, 717-726, 2005.

Kimbell, G., Ritchie, J., and Henderson, A.: Three-dimensional gravity and magnetic modelling of the Irish sector of the NE Atlantic margin, Tectonophysics, 486, 36-54, 2010.

Kimbell, G. S. and Richards, P. C.: The three-dimensional lithospheric structure of the Falkland Plateau region based on gravity modelling, J. Geol. Soc., 165, 795-806, 2008.

Kimura, G. and Ludden, J.: Peeling oceanic crust in subduction zones, Geology, 23, 217-220, 1995.

Kimura, H., Takeda, T., Obara, K., and Kasahara, K.: Seismic Evidence for Active Underplating Below the Megathrust Earthquake Zone in Japan, Science, 329, 210-214, 2010.

Klingelhoefer, F., Edwards, R., Hobbs, R., and England, R.: Crustal structure of the NE Rockall Trough from wide-angle seismic data modeling, J. Geophys. Res., 110, doi:10.1029/2005JB003763, 2005.

Klingelhoefer, F., Lafoy, Y., Collot, J., Cosquer, E., Geli, L., Nouze, H., and Vially, R.: Crustal structure of the basin and ridge system west of New Caledonia (southwest Pacific) from 
wide-angle and reflection seismic data, J. Geophys. Res., 112, doi:10.1029/2007JB005093, 2007.

Kodaira, S., Mjelde, R., Gunnarsson, K., Shiobara, H., and Shimamura, H.: Structure of the Jan Mayen microcontinent and implications for its evolution, Geophys. J. Int., 132, 383-400, 1998.

Kodaira, S., Sato, T., Takahashi, N., Ito, A., Tamura, Y., Tatsumi, Y., and Kaneda, Y.: Seismological evidence for variable growth of crust along the Izu intraoceanic arc, J. Geophys. Res., 112, doi:10.1029/2006JB004593, 2007a.

Kodaira, S., Sato, T., Takahashi, N., Miura, S., Tamura, Y., and Kaneda, Y.: New seismological constraints on growth of continental crust in the Izu-Bonin intra-oceanic arc, Geology, 35, 1031-1034, 2007b.

Konig, M. and Jokat, W.: Advanced insights into magmatism and volcanism of the Mozambique Ridge and Mozambique Basin in the view of new potential field data, Geophys. J. Int, 180, 158$180,2010$.

Kono, Y., Ishikawa, M., Harigane, Y., Michibayashi, K., and Arima, M.: P- and S-wave velocities of the lowermost crustal rocks from the Kohistan arc: Implications for seismic Moho discontinuity attributed to abundant garnet, Tectonophysics, 467, 44-54, 2009.

Kopp, H., Klaeschen, D., Flueh, E. R., Bialas, J., and Reichert, C.: Crustal structure of the Java margin from seismic wideangle and multichannel reflection data, J. Geophys. Res., 107, doi:10.1029/2000JB000095, 2002.

Kopp, H., Kopp, C., Phipps Morgan, J., Flueh, E. R., Weinrebe, W., and Morgan, W. J.: Fossil hot spot-ridge interaction in the Musicians Seamount Province: Geophysical investigations of hot spot volcanism at volcanic elongated ridges, J. Geophys. Res., 108, doi:10.1029/2002JB002015, 2003.

Kopp, H., Flueh, E. R., Papenberg, C., and Klaeschen, D.: Seismic investigations of the O'Higgins Seamount Group and Juan Fernandez Ridge: Aseismic ridge emplacement and lithosphere hydration, Tectonics, 23, doi:10.1029/2003TC001590, 2004.

Koppers, A. A. and Watts, A. B.: Intraplate Seamounts as a Window into Deep Earth Processes, Oceanography, 23, 42-57, 2010.

Lapierre, H., Ortiz, L. E., Abouchami, W., Monod, O., Coulon, C., and Zimmermann, J.-L.: A crustal section of an intra-oceanic island arc: The Late Jurassic-Early Cretaceous Guanajuato magmatic sequence, central Mexico, Earth Planet. Sci. Lett., 108, 61-77, 1992.

Larter, R., Vanneste, L. E., Morris, P., and Smythe, D. K.: Structure and tectonic evolution of the South Sandwich arc, in: IntraOceanic Subduction Systems: Tectonic and Magmatic Processes, edited by: Larter, R. and Leat, P., Geol. Soc. Spec. Pub., Geol. Soc. London, 219, 255-284, 2003.

Leahy, G. M., Collins, J. A., Wolfe, C. J., Laske, G., and Solomon, S. C.: Underplating of the Hawaiian Swell: evidence from teleseismic receiver functions, Geophys. J. Int., 183, 313-329, 2010.

Leat, P., Smellie, J., Millar, I., and Larter, R.: Magmatism in the South Sandwich arc, in: Intra-Oceanic Subduction Systems: Tectonic and Magmatic Processes, edited by: Larter, R. and Leat, P., Geol. Soc. Spec. Pub., Geol. Soc. London, 219, 285-313, 2003.

Lebedeva-Ivanova, N. N., Zamansky, Y. Y., Langinen, A. E., and Sorokin, M. Y.: Seismic profiling across the Mendeleev Ridge at $82^{\circ} \mathrm{N}$ : evidence of continental crust, Geophys. J. Int., 165, 527544, 2006.

Lebedeva-Ivanova, N. N., Gee, D. G., and Sergeyev, M. B.: Chapter 26 Crustal structure of the East Siberian continental margin, Pod- vodnikov and Makarov basins, based on refraction seismic data (TransArctic 1989-1991), Geol. Soc. Mem., 35, 395-411, 2011.

Lizarralde, D., Holbrook, W. S., McGeary, S., Bangs, N., and Diebold, J.: Crustal construction of a volcanic arc, wide-angle seismic results from the western Alaska Peninsula, J. Geophys. Res., 107, doi:10.1029/2001JB000230, 2002.

Ludwig, W. J., Nafe, J. E., and Drake, C. L.: Seismic Refraction, in: The Sea, edited by: Maxwell, A., Wiley-Interscience, 4, 53-84, 1970.

Lundin, E. R. and Doré, A. G.: Hyperextension, serpentinization, and weakening: A new paradigm for rifted margin compressional deformation, Geology, 39, 347-350, doi:10.1130/G31499.1, 2011.

Magnani, M. B., Zelt, C. A., Levander, A., and Schmitz, M.: Crustal structure of the South American-Caribbean plate boundary at $67^{\circ} \mathrm{W}$ from controlled source seismic data, J. Geophys. Res., 114, 1-23, 2009.

Manatschal, G.: New models for evolution of magma-poor rifted margins based on a review of data and concepts from West Iberia and the Alps, Int. J. Earth Sci., 93, 432-466, 2004.

Mann, P. and Taira, A.: Global tectonic significance of the Solomon Islands and Ontong Java Plateau convergent zone, Tectonophysics, 389, 137-190, 2004.

Marcaillou, B., Charvis, P., and Collot, J.-Y.: Structure of the Malpelo Ridge (Colombia) from seismic and gravity modelling, Mar. Geophys. Res., 27, 289-300, 2006.

Marks, K. and Sandwell, D.: Analysis of geoid height versus topography for oceanic plateaus and swells using nonbiased linear regression, J. Geophys. Res., 96, 8045-8055, 1991.

Martinod, J., Funiciello, F., Faccenna, C., Labanieh, S., and Regard, V.: Dynamical effects of subducting ridges: insights from 3-D laboratory models, Geophys. J. Int., 163, 1137-1150, 2005.

Mason, W. G., Moresi, L., Betts, P. G., and Miller, M. S.: Threedimensional numerical models of the influence of a buoyant oceanic plateau on subduction zones, Tectonophysics, 483, 7179, 2010.

Mauffret, A. and Leroy, S.: Seismic stratigraphy and structure of the Caribbean igneous province, Tectonophysics, 283, 61-104, 1997.

McCrory, P. A. and Wilson, D. S.: A kinematic model for the formation of the Siletz-Crescent forearc terrane by capture of coherent fragments of the Farallon and Resurrection plates, Tectonics, 32, 718-736, 2013.

Mihut, D. and Muller, R.: Volcanic margin formation and Mesozoic rift propagators in the Cuvier Abyssal Plain off Western Australia, J. Geophys. Res., 103, 27135-27149, 1998.

Miller, D. J. and Christensen, N. I.: Seismic signature and geochemistry of an island arc: A multidisciplinary study of the Kohistan accreted terrane, northern Pakistan, J. Geophys. Res., 99, 11623 11642, 1994.

Miura, R., Nakamura, Y., Koda, K., Tokuyama, H., and Coffin, M.: "Rootless" serpentinite seamount on the southern Izu-Bonin forearc: Implications for basal erosion at convergent plate margins, Geology, 32, 541-544, 2004a.

Miura, S., Suyehiro, K., Shinohara, M., Takahashi, N., Araki, E., and Taira, A.: Seismological structure and implications of collision between the Ontong Java Plateau and Solomon Island Arc from ocean bottom seismometer-airgun data, Tectonophysics, 389, 191-220, 2004b. 
Mohriak, W. U., Nobrega, M., Odegard, M. E., Gomes, B. S., and Dickson, W. G.: Geological and geophysical interpretation of the Rio Grande Rise, south-eastern Brazilian margin: extensional tectonics and rifting of continental and oceanic crusts, Petrol. Geosci., 16, 231-245, 2010.

Molnar, P. and Gray, D.: Subduction of continental lithosphere: Some constraints and uncertainties, Geology, 7, 58-62, 1979.

Monger, J., Souther, J., and Gabrielse, H.: Evolution of the Canadian Cordillera: a plate tectonic model, Am. J. Sci., 272, 577602, 1972.

Moore, J. C.: Tectonics and hydrogeology of accretionary prisms: role of the décollement zone, J. Struct. Geol., 11, 95-106, 1989.

Moore, V. M. and Wiltscko, D. V.: Syncollisional delamination and tectonic wedge development in convergent orogens, Tectonics, 23, doi:10.1029/2002TC001430, 2004.

Morewood, N. C., Mackenzie, G. D., Shannon, P. M., O’Reilly, B. M., Readman, P. W., and Makris, J.: The crustal structure and regional development of the Irish Atlantic margin region, Geol. Soc. London, Petrol. Geol. Conf. series, 6, 1023-1033, 2005.

Müller, R. D., Gaina, C., Roest, W. R., and Hansen, D. L.: A recipe for microcontinent formation, Geology, 29, 203-206, 2001.

Nakamura, M. and Umedu, N.: Crustal thickness beneath the Ryukyu arc from travel-time inversion, Earth Planets Space, 61, 1191-1195, 2009.

Nakanishi, A., Kurashimo, E., Tatsumi, Y., Yamaguchi, H., Miura, S., Kodaira, S., Obana, K., Takahashi, N., Tsuru, T., Kaneda, Y., Iwasaki, T., and Hirata, N.: Crustal evolution of the southwestern Kuril Arc, Hokkaido Japan, deduced from seismic velocity and geochemical structure, Tectonophysics, 472, 105-123, 2009.

Nishizawa, A., Kaneda, K., Katagiri, Y., and Kasahara, J.: Crustal structure around the Oki-Daito Ridge in the northern West Philippine Basin, Joint Meeting for Earth and Planetary Science, 22-27 May 2005, Chiba, Japan, j078-004, 2005.

Nishizawa, A., Kaneda, K., Katagiri, Y., and Kasahara, J.: Variation in crustal structure along the Kyushu-Palau Ridge at $15-21^{\circ} \mathrm{N}$ on the Philippine Sea plate based on seismic refraction profiles, Earth Planets Space, 59, 17-20, 2007.

Nur, A. and Ben-Avraham, Z.: Oceanic Plateaus, the Fragmentation of Continents, and Mountain Building, J. Geophys. Res., 87, 3644-3661, 1982.

Operto, S. and Charvis, P.: Kerguelen Plateau: A volcanic passive margin fragment?, Geology, 23, 137-140, 1995.

O'Reilly, B. M., Hauser, F., Jacob, A. B., and Shannon, P. M.: The lithosphere below the Rockall Trough: wide-angle seismic evidence for extensive serpentinisation, Tectonophysics, 255, 1-23, 1996.

Oxburgh, E.: Flake tectonics and continental collision, Nature, 239, 202-204, 1972.

Parsiegla, N., Gohl, K., and Uenzelmann-Neben, G.: The Agulhas Plateau: structure and evolution of a Large Igneous Province, Geophys. J. Int., 174, 336-350, 2008.

Patriat, M., Klingelhoefer, F., Aslanian, D., Contrucci, I., Gutscher, M.-A., Talandier, J., Avedik, F., Francheteau, J., and Weigel, W.: Deep crustal structure of the Tuamotu plateau and Tahiti (French Polynesia) based on seismic refraction data, Geophys. Res. Lett., 29, doi:10.1029/2001GL013913, 2002.

Pearcy, L. G., DeBari, S. M., and Sleep, N. H.: Mass balance calculations for two sections of island arc crust and implications for the formation of continents, Earth Planet. Sci. Lett., 96, 427-442, 1990.

Peirce, C. and Barton, P.: Crustal structure of the Madeira-Tore Rise, eastern North Atlantic-results of a DOBS wide-angle and normal incidence seismic experiment in the Josephine Seamount region, Geophys. J. Int., 106, 357-378, 1991.

Peron-Pinvidic, G. and Manatschal, G.: From microcontinents to extensional allochthons: witnesses of how continents rift and break apart?, Petrol. Geosci., 16, 1-10, 2010.

Petterson, M., Neal, C., Mahoney, J., Kroenke, L., Saunders, A., Babbs, T., Duncan, R., Tolia, D., and McGrail, B.: Structure and deformation of north and central Malaita, Solomon Islands: tectonic implications for the Ontong Java Plateau-Solomon arc collision, and for the fate of oceanic plateaus, Tectonophysics, 183, 1-33, 1997.

Petterson, M., Babbs, T., Neal, C., Mahoney, J., Saunders, A., Duncan, R., Tolia, D., Magua, R., Qopoto, C., Mahoaa, H., and Natogga, D.: Geological-tectonic framework of Solomon Islands, SW Pacific: crustal accretion and growth within an intraoceanic setting, Tectonophysics, 301, 35-60, 1999.

Petterson, M. G.: A Review of the geology and tectonics of the Kohistan island arc, north Pakistan, in: The Evolving Continents: Understanding Processes of Continental Growth, edited by: Kusky, T. M., Zhai, M.-G., and Xiao, W., Geol. Soc. Spec. Pub., Geol. Soc. London, 338, 287-327, 2010.

Poselov, V. A., Kaminsky, V. D., Butsenko, V. V., Murzin, R. R., and Komaritsyn, A. A.: Experience in applying the geological criteria of Article 76 to the definition of the outer limit of the extended continental shelf of the Russian Federation in Arctic Ocean, in: The Fourth International Conference on Arctic Margins, edited by: Scott, R. A. and Thurston, D. K., 199-205, 2003.

Pubellier, M. and Meresse, F.: Phanerozoic growth of Asia: Geodynamic processes and evolution, J. Asian Earth Sci., 72, 118-128, 2013.

Pubellier, M., Bader, A. G., Rangin, C., Deffontaines, B., and Quebral, R.: Upper plate deformation induced by subduction of a volcanic arc: the Snellius Plateau (Molucca Sea, Indonesia and Mindanao, Philippines), Tectonophysics, 304, 345-368, doi:10.1016/S0040-1951(98)00300-X, 1999.

Pubellier, M., Ego, F., Chamot-Rooke, N., and Rangin, C.: The building of pericratonic mountain ranges: structural and kinematic constraints applied to GIS-based reconstructions of SE Asia, B. Soc. Geol. FR, 174, 561-584, 2003.

Pubellier, M., Monnier, C., Maury, R., and Tamayo, R.: Plate kinematics, origin and tectonic emplacement of supra-subduction ophiolites in SE Asia, Tectonophysics, 392, 9-36, 2004.

Puchtel, I., Hofmann, A., Mezger, K., Jochum, K., Shchipansky, A., and Samsonov, A.: Oceanic plateau model for continental crustal growth in the Archaean: A case study from the Kostomuksha greenstone belt, NW Baltic Shield, Earth Planet. Sci. Lett., 155, 57-74, 1998.

Queaño, K. L., Ali, J. R., Pubellier, M., Yumul, G. P., and Dimalanta, C. B.: Reconstructing the Mesozoic-early Cenozoic evolution of northern Philippines: Clues from palaeomagnetic studies on the ophiolitic basement of the Central Cordillera, Geophys. J. Int., 178, 1317-1326, 2009.

Ramachandran, K., Hyndman, R. D., and Brocher, T. M.: Regional $\mathrm{P}$-wave velocity structure of the Northern Cascadia Subduction Zone, J. Geophys. Res., 111, 1-15, 2006. 
Recq, M., Goslin, J., Charvis, P., and Operto, S.: Small-scale crustal variability within an intraplate structure: the Crozet Bank (southern Indian Ocean), Geophys. J. Int., 134, 145-156, 1998.

Reston, T.: Rifted Margins: Building Blocks of Later Collision, in: Arc-Continent Collision, edited by: Brown, D., Ryan, P. D., Reston, T., and Manatschal, G., Frontiers in Earth Sciences, Springer Berlin Heidelberg, 3-21, 2011.

Reston, T., Pennell, J., Stubenrauch, A., Walker, I., and PerezGussinye, M.: Detachment faulting, mantle serpentinization, and serpentinite-mud volcanism beneath the Porcupine Basin, southwest of Ireland, Geology, 29, 587-590, 2001.

Reyners, M., Eberhart-Phillips, D., Stuart, G., and Nishimura, Y.: Imaging subduction from the trench to $300 \mathrm{~km}$ depth beneath the central North Island, New Zealand, with $V_{\mathrm{p}}$ and $V_{\mathrm{p}} / V_{\mathrm{s}}$, Geophys. J. Int., 165, 565-583, 2006.

Richards, M. A., Duncan, R. A., and Courtillot, V. E.: Flood Basalts and Hot-Spot Tracks: Plume Heads and Tails, Science, 246, 103 $107,1989$.

Richardson, K. R., White, R. S., England, R. W., and Fruehn, J.: Crustal structure east of the Faroe Islands; mapping sub-basalt sediments using wide-angle seismic data, Petrol. Geosci., 5, doi:10.1144/petgeo.5.2.161, 1999.

Ridley, V. A. and Richards, M. A.: Deep crustal structure beneath large igneous provinces and the petrologic evolution of flood basalts, Geochem. Geophys. Geosyst., 11, doi:10.1029/2009GC002935, 2010.

Rioux, M., Hacker, B., Mattinson, J., Kelemen, P. B., Blusztajn, J., and Gehrels, G. E.: Magmatic development of an intra-oceanic arc: High-precision U-Pb zircon and whole-rock isotopic analyses from the accreted Talkeetna arc, south-central Alaska, Geol. Soc. Am. Bull., 119, 1168-1184, 2007.

Rioux, M., Mattinson, J., Hacker, B., Kelemen, P., Blusztajn, J., Hanghoj, K., and Gehrels, G.: Intermediate to felsic middle crust in the accreted Talkeetna arc, the Alaska Peninsula and Kodiak Island, Alaska: An analogue for low-velocity middle crust in modern arcs, Tectonics, 29, doi:10.1029/2009TC002541, 2010.

Sager, W. W.: What built Shatsky Rise, a mantle plume or ridge tectonics?, in: Plates, plumes, and paradigms, edited by: Foulger, G., Natland, J., Presnall, D., and Anderson, D., Geol. Soc. A. SP., Geol. Soc. Am., 388, 721-733, 2005.

Sallares, V., Charvis, P., Flueh, E. R., and Bialas, J.: Seismic structure of Cocos and Malpelo Volcanic Ridges and implications for hot spot-ridge interaction, J. Geophys. Res., 108, doi:10.1029/2003JB002431, 2003.

Sallares, V. S., Charvis, P., Flueh, E. R., Bialas, J., and the SALIERI Scientific Party: Seismic structure of the Carnegie ridge and the nature of the Galapagos hotspot, Geophys. J. Int., 161, 763-788, 2005.

Sandwell, D. T. and Fialko, Y.: Warping and cracking of the Pacific plate by thermal contraction, J. Geophys. Res., 109, doi:10.1029/2004JB003091, 2004.

Sandwell, D. T. and MacKenzie, K. R.: Geoid Height Versus Topography for Oceanic Plateaus and Swells, J. Geophys. Res., 94, 7403-7418, 1989.

Sapin, F., Pubellier, M., Lahfid, A., Janots, D., Aubourg, C., and Ringenbach, J.-C.: Onshore record of the subduction of a crustal salient: example of the NW Borneo Wedge, Terra Nova, 23, 232240, 2011
Savva, D., Meresse, F., Pubellier, M., Chamot-Rooke, N., Lavier, L., Po, K. W., Franke, D., Steuer, S., Sapin, F., Auxietre, J., and Lamy, G.: Seismic evidence of hyper-stretched crust and mantle exhumation offshore Vietnam, Tectonophysics, 608, 72-83, 2013.

Schellart, W. P., Lister, G. S., and Toy, V. G.: A Late Cretaceous and Cenozoic reconstruction of the Southwest Pacific region: Tectonics controlled by subduction and slab rollback processes, Earth Sci. Rev., 76, 191-233, 2006.

Scherwath, M., Kopp, H., Flueh, E., Henrys, S., Sutherland, R., Stagpoole, V., Barker, D., Reyners, M., Bassett, D., Planert, L., and Dannowski, A.: Fore-arc deformation and underplating at the northern Hikurangi margin, New Zealand, J. Geophys. Res., 115, doi:10.1029/2009JB006645, 2010.

Schmandt, B. and Humphreys, E.: Seismically imaged relict slab from the $55 \mathrm{Ma}$ Siletzia accretion to the northwest United States, Geology, 39, 175-178, 2011.

Scholl, D. W. and von Huene, R.: Subduction zone recycling processes and the rock record of crustal suture zones, Can. J. Earth Sci., 47, 633-654, 2010.

Schubert, G. and Sandwell, D.: Crustal volumes of the continents and of oceanic and continental submarine plateaus, Earth Planet. Sci. Lett., 92, 234-246, 1989.

Scotchman, I., Gilchrist, G., Kusznir, N., Roberts, A., and Fletcher, R.: The breakup of the South Atlantic Ocean: formation of failed spreading axes and blocks of thinned continental crust in the Santos Basin, Brazil and its consequences for petroleum system development, Geol. Soc. London, Petrol. Geol. Conf. series, 7, 855-866, 2010.

Sdrolias, M. and Müller, R. D.: Controls on back-arc basin formation, Geochem. Geophys. Geosyst., 7, Q04016, doi:10.1029/2005GC001090, 2006

Searle, M. P., Khan, M. A., Fraser, J. E., Gough, S. J., and Jan, M. Q.: The tectonic evolution of the Kohistan-Karakoram collision belt along the Karakoram Highway transect, north Pakistan, Tectonics, 18, 929-949, 1999.

Sengor, A. M. C.: Mid-Mesozoic closure of Permo-Triassic Tethys and its implications, Nature, 279, 590-593, 1979.

Seno, T.: Conditions for a crustal block to be sheared off from the subducted continental lithosphere: What is an essential factor to cause features associated with collision?, J. Geophys. Res., 113, doi:10.1029/2007JB005038, 2008.

Sevilla, W. I., Ammon, C. J., Voight, B., and Angelis, S. D.: Crustal structure beneath the Montserrat region of the Lesser Antilles island arc, Geochem. Geophys. Geosyst., 11, doi:10.1029/2010GC003048, 2010.

Shillington, D. J., Avendonk, H. J. A. V., Holbrook, W. S., Kelemen, P. B., and Hornbach, M. J.: Composition and structure of the central Aleutian island arc from arc-parallel wide-angle seismic data, Geochem. Geophys. Geosyst., 5, doi:10.1029/2004GC000715, 2004.

Shor, G., Kirk, H., and Menard, H.: Crustal structure of Melanesian Area, J. Geophys. Res., 76, 2562-2586, 1971.

Shulgin, A., Kopp, H., Mueller, C., Lueschen, E., Planert, L., Engels, M., Flueh, E. R., Krabbenhoeft, A., and Djajadihardja, Y.: Sunda-Banda arc transition: Incipient continent-island arc collision (northwest Australia), GRL, 36, doi:10.1029/2009GL037533, 2009. 
Shulgin, A., Kopp, H., Mueller, C., Planert, L., Lueschen, E., Flueh, E. R., and Djajadihardja, Y.: Structural architecture of oceanic plateau subduction offshore Eastern Java and the potential implications for geohazards, Geophys. J. Int., 184, 12-28, 2011.

Sinha, M. C., Louden, K. E., and Parsons, B.: The crustal structure of the Madagascar Ridge, Geophys. J. R. astr. Soc., 66, 351-377, 1981.

Snoke, A. and Barnes, C.: The development of tectonic concepts for the Klamath Mountains province, California and Oregon, in: Geological studies in the Klamath Mountains province, California and Oregon: A volume in honor of William P. Irwin, edited by: Snoke, A. and Barnes, C., Geol. Soc. A. SP., Geol. Soc. Am., 410, 1-29, 2006.

Snyder, D. B.: Lithospheric growth at margins of cratons, Tectonophysics, 355, 7-22, 2002.

Snyder, D. B., Pilkington, M., Clowes, R. M., and Cook, F. A.: The underestimated Proterozoic component of the Canadian Cordillera accretionary margin, in: Earth Accretionary Systems in Space and Time, edited by: Cawood, P. and Kroner, A., Geol. Soc. London Spec. Pub., 318, 257-271, 2009.

Stern, R. J. and Scholl, D. W.: Yin and yang of continental crust creation and destruction by plate tectonic processes, Int. Geol. Rev., 52, 1-31, 2010.

Stern, R. J., Fouch, M. J., and Klemperer, S. L.: An overview of the Izu-Bonin-Mariana subduction factory, Geoph. Monog. Series, 138, 175-222, 2003.

Sutherland, R., Collot, J., Lafoy, Y., Logan, G. A., Hackney, R., Stagpoole, V., Uruski, C., Hashimoto, T., Higgins, K., Herzer, R. H., Wood, R., Mortimer, N., and Rollet, N.: Lithosphere delamination with foundering of lower crust and mantle caused permanent subsidence of New Caledonia Trough and transient uplift of Lord Howe Rise during Eocene and Oligocene initiation of Tonga-Kermadec subduction, western Pacific, Tectonics, 29, doi:10.1029/2009TC002476, 2010.

Takahashi, N., Kodaira, S., Klemperer, S. L., Tatsumi, Y., Kaneda, Y., and Suyehiro, K.: Crustal structure and evolution of the Mariana intra-oceanic island arc, Geology, 35, 203-206, 2007.

Takahashi, N., Kodaira, S., Tatsumi, Y., Kaneda, Y., and Suyehiro, K.: Structure and growth of the Izu-Bonin-Mariana arc crust: 1. Seismic constraint on crust and mantle structure of the Mariana arc-back-arc system, J. Geophys. Res., 113, doi:10.1029/2007JB005120, 2008.

Takahashi, N., Kodaira, S., Tatsumi, Y., Yamashita, M., Sato, T., Kaiho, Y., Miura, S., No, T., Takizawa, K., and Kaneda, Y.: Structural variations of arc crusts and rifted margins in the southern Izu-Ogasawara arc-back arc system, Geochem. Geophys. Geosyst., 10, doi:10.1029/2008GC002146, 2009.

Tatsumi, Y., Kani, T., Ishizuka, H., Maruyama, S., and Nishimura, Y.: Activation of Pacific mantle plumes during the Carboniferous: Evidence from accretionary complexes in southwest Japan, Geology, 28, 580-582, 2000.

Tatsumi, Y., Shukuno, H., Tani, K., Takahashi, N., Kodaira, S., and Kogiso, T.: Structure and growth of the Izu-Bonin-Mariana arc crust: 2 . Role of crust-mantle transformation and the transparent Moho in arc crust evolution, J. Geophys. Res., 113, doi:10.1029/2007JB005121, 2008.

Taylor, B.: The single largest oceanic plateau: Ontong JavaManihiki-Hikurangi, Earth Planet. Sci. Lett., 241, 372-380, 2006.
Tetreault, J. L. and Buiter, S. J. H.: Geodynamic models of terrane accretion: Testing the fate of island arcs, oceanic plateaus, and continental fragments in subduction zones, J. Geophys. Res., 117, B08403, doi:10.1029/2012JB009316, 2012.

van der Velden, A. J. and Cook, F. A.: Relict subduction zones in Canada, J. Geophys. Res., 110, doi:10.1029/2004JB003333, 2005.

van Hunen, J., van den Berg, A. P., and Vlaar, N. J.: On the role of subducting oceanic plateaus in the development of shallow flat subduction, Tectonophysics, 352, 317-333, 2002.

van Staal, C. R., Rogers, N., and Taylor, B. E.: Formation of low-temperature mylonites and phyllonites by alkalimetasomatic weakening of felsic volcanic rocks during progressive, subduction-related deformation, J. Struct. Geol., 23, 903 921, 2001.

Vink, G. E., Morgan, W. J., and Zhao, W.-L.: Preferential Rifting of Continents: A Source of Displaced Terranes, J. Geophys. Res., 89, 10072-10076, 1984.

Viso, R. F., Larson, R. L., and Pockalny, R. A.: Tectonic evolution of the Pacific-Phoenix-Farallon triple junction in the South Pacific Ocean, Earth Planet. Sci. Lett., 233, 179-194, 2005.

Vogt, U., Makris, J., O’Reilly, B. M., Hauser, F., Readman, P. W., Jacob, A. W. B., and Shannon, P. M.: The Hatton Basin and continental margin: Crustal structure from wide-angle seismic and gravity data, J. Geophys. Res., 103, 12545-12566, doi:10.1029/98JB00604, 1998.

Wakita, K. and Metcalfe, I.: Ocean Plate Stratigraphy in East and Southeast Asia, J. Asian Earth Sci., 24, 679-702, 2005.

Wakita, K., Pubellier, M., and Windley, B. F.: Tectonic processes, from rifting to collision via subduction, in SE Asia and the western Pacific: A key to understanding the architecture of the Central Asian Orogenic Belt, Lithosphere, 5, 265-276, 2013.

Waldron, J. W. F. and van Staal, C. R.: Taconian orogeny and the accretion of the Dashwoods block: A peri-Laurentian microcontinent in the Iapetus Ocean, Geology, 29, 811-814, 2001.

Walther, C. H.: The crustal structure of the Cocos ridge off Costa Rica, J. Geophys. Res., 108, B3, doi:10.1029/2001JB000888, 2003.

Watts, A. B., Koppers, A. A., and Robinson, D. P.: Seamount subduction and earthquakes, Oceanography, 23, 166-173, 2010.

Weigel, W. and Grevemeyer, I.: The Great Meteor seamount: seismic structure of a submerged intraplate volcano, J. Geodyn., 28, 27-40, 1999.

Wessel, P. and Smith, W. H. F.: Free software helps map and display data, Eos Trans. AGU, 72, 441-446, 1991.

Wessel, P., Sandwell, D. T., and Kim, S.-S.: The Global Seamount Census, Oceanography, 23, 24-33, 2010.

White, R., Tarney, J., Kerr, A., Saunders, A., Kempton, P., Pringle, M., and Klaver, G.: Modification of an oceanic plateau, Aruba, Dutch Caribbean: Implications for the generation of continental crust, Lithos, 46, 43-68, 1998.

White, R. S. and Smith, L. K.: Crustal structure of the Hatton and the conjugate east Greenland rifted volcanic continental margins, NE Atlantic, J. Geophys. Res., 114, B2, doi:10.1029/2008JB005856, 2009.

Whitmarsh, R., Langford, J., Buckley, J., Bailey, R., and Blundell, D.: The crustal structure beneath Porcupine Ridge as determined by explosion seismology, Earth Planet. Sci. Lett., 22, 197-204, 1974. 
Windley, B. F., Alexeiev, D., Xiao, W., Kröner, A., and Badarch, G.: Tectonic models for accretion of the Central Asian Orogenic Belt, J. Geol. Soc. London, 164, 31-47, 2007.

Woods, M. T. and Okal, E. A.: The structure of the Nazca ridge and Sala y Gomez seamount chain from the dispersion of Rayleigh waves, Geophys. J. Int., 117, 205-222, 1994.

Wright, J. E. and Wyld, S. J.: The Rattlesnake Creek terrane, Klamath Mountains, California: An early Mesozoic volcanic arc and its basement of tectonically disrupted oceanic crust, Geol. Soc. Am. Bull., 106, 1033-1056, 1994.

Yumul, G. P., Dimalanta, C. B., III, T. A. T., and Ramos, E. G.: Baguio Mineral District: An oceanic arc witness to the geological evolution of northern Luzon, Philippines, Island Arc, 17, 432442, 2008.
Yumul, G. P., Dimalanta, C. B., Marquez, E. J., and Queaño, K. L.: Onland signatures of the Palawan microcontinental block and Philippine mobile belt collision and crustal growth process: A review, J. Asian Earth Sci., 34, 610-623, 2009.

Zagorevski, A., Lissenberg, C., and van Staal, C.: Dynamics of accretion of arc and backarc crust to continental margins: Inferences from the Annieopsquotch accretionary tract, Newfoundland Appalachians, Tectonophysics, 479, 150-164, 2009.

Zalán, P. V., do Carmo G. Severino, M., Rigoti, C. A., Magnavita, L. P., Oliveira, J. A. B., and Viana, A. R.: An Entirely New 3DView of the Crustal and Mantle Structure of a South Atlantic Passive Margin - Santos, Campos and Espírito Santo Basins, Brazil, in: AAPG Search and Discovery Article, 30177, 1-12, 2011. 